\title{
THE “NEGATIVE” ASSIMILATION OF IMMIGRANTS: A SPECIAL CASE
}

\author{
BARRY R. CHISWICK AND PAUL W. MILLER
}

\begin{abstract}
The authors address whether "negative" assimilation among immigrants living in the United States occurs if skills are highly transferable internationally. They outline the conditions for negative assimilation in the context of the traditional immigration assimilation model, in which negative assimilation arises not from a deterioration of skills but from a decline in the wages afforded by skills coincident with the duration of residence. The authors use U.S. Census data from 1980, 1990, and 2000 to test the hypothesis on immigrants to the United States from English-speaking developed countries. They present comparisons with native-born workers to determine whether the findings are sensitive to immigrant cohort quality effects and find that even after controlling for these effects, negative assimilation still occurs for immigrants in the sample. They also find that negative assimilation occurs for immigrants from English-speaking developed countries living in Australia and for immigrants from Nordic countries living in Sweden.
\end{abstract}

$\mathbf{F}$ rom the beginning of the research on the economic or labor market assimilation of immigrants, the literature has focused on the degree of improvement in their economic status with duration in their destination country (Chiswick 1978, 1979). This improvement has been found for all immigrantreceiving countries, time periods, and data sets that have been studied. The theoretical underpinning for this finding is the interna-

Barry R. Chiswick is Professor and Chair of the Department of Economics at George Washington University and Director of the Migration Studies Program at IZABonn. This paper was written while he was at the University of Illinois at Chicago. Paul Miller is a professor in the School of Economics and Finance at Curtin University in Perth, Australia. He is a Research Fellow at IZABonn.

The authors thank Derby Voon for research assistance. They also thank participants at the IZA's Fifth Annual Migration Meeting, IZA-Bonn, May 2008; at the Southern Economics Association Annual Meeting, Washington DC, November 2008; at the Stockholm University Linneaus Center for Integration Studies, December 2008; at the Eastern Economics Association tional transferability of skills. In this paper, we address whether positive assimilation occurs if skills are highly transferable internationally. Indeed, the question arises, might there be the appearance of negative assimilation, that is, that earnings decline coincident with duration in the destination if the immigrant's skills are highly transferable across countries?

To answer this question, we analyze the earnings of adult, foreign-born men from English Speaking Developed Countries (ESDC) in the 1980, 1990, and 2000 U.S. Censuses.

\footnotetext{
Annual Meeting, New York, February 2009; and at Monash University in May 2009, for helpful comments. Chiswick acknowledges research support from the Smith Richardson Foundation. Miller acknowledges financial assistance from the Australian Research Council. An earlier version with the same title is IZA-Institute for the Study of Labor, Discussion Paper No. 3563.

To obtain full sets of results on selected data, please contact the authors at brchis@gwu.edu or paul.miller@ curtin.au.edu.
} 


\section{The Assimilation Model}

The immigrant assimilation model begins with the implicit assumption that immigrants possess a set of skills that they acquired in the lower-income origin that are not perfectly transferable to the higher-income destination. These skills include schooling, on-the-job training, language, labor market information, labor market networks, occupational licensing or credentials, occupationspecific technical training, and the customs or cultural characteristics that influence productivity, and hence earnings, in the origin and destination labor markets. When the immigrant moves from the origin to the destination, at least some of these skills are less than perfectly transferable, giving the immigrant incentives to make explicit (e.g., schooling) or implicit (e.g., learning-by-living) investments in destination-specific skills. Some of these investments may be intended to increase the transferability of skills acquired in the origin, such as when an immigrant physician studies for the Foreign Medical Examination. Other investments may be undertaken to acquire new skills, such as when an immigrant lawyer studies for an MBA.

Immigrants have an incentive to make these investments sooner rather than later for three reasons. First, if these post-migration human capital investments are profitable, in the sense that the net present value of the stream of costs and benefits is positive (or the internal rate of return exceeds the discount rate), the net present value of the investments are greater the sooner they are made. Second, a delay in making these investments reduces the number of future time periods in which immigrants will receive these benefits, thereby lowering the rate of return from the investment. Finally, as duration in the destination increases, explicit investments, and even learning-byliving, will increase immigrants' knowledge and other skills relevant for the destination labor market, thereby raising the opportunity cost of the time devoted to investment in destination skills. This opportunity cost, of course, lowers the net present value and the rate of return on these investments (Ben-Porath 1967).
If skills are not readily transferable internationally, immigrants' earnings will be lower than those for natives with similar skills. Moreover, the greater the extent to which immigrants invest in skills in the destination country, the lower the reported earnings are during the investment period. Earnings then increase as the extent of the investment decreases over time (the most profitable destination investments are made first), and as returns are received on previous investments. As a result, the earningsduration profile is upward rising, but at a decreasing rate. This accounts for the use of the quadratic duration-of-residence variable in the standard analysis of immigrant post-migration labor market adjustment (Chiswick 1978). The greater the steepness of the profile, the greater the extent of the investments in destination human capital, and the greater the rate of return from these investments. By implication, the earningsduration profile would be horizontal if there were no investment, explicit or implicit, in destination human capital.

Let us consider two countries with equal average levels of earnings for individuals with a given level of schooling, labor market information, and other human capital relevant in the origin or destination. Consider, too, the skills to be perfectly internationally transferable between the two countries and that there is no skill employed in one that is not also used in the other country. Moreover, for simplicity, let us assume that in neither the origin nor the destination country are there investments in on-the-job training.

Bear in mind that for each skill level there exists variation in the distribution of wage offers around the mean. Workers in country X search not only in X but also in country $\mathrm{Y}^{1} \mathrm{~A}$ given worker will migrate from $\mathrm{X}$ to $\mathrm{Y}$ if and only if by random selection he or she receives a sufficiently high wage offer in Y so that this wage offer is greater than the best wage offer in $\mathrm{X}$ by an amount sufficient to compensate for the out-of-pocket, time, and psychic costs of migration. Upon receiving this high-wage offer, the worker will move

\footnotetext{
${ }^{1}$ The search process may involve a temporary or shortduration sojourn in country $\mathrm{Y}$.
} 
from $\mathrm{X}$ to $\mathrm{Y}$, and under the assumptions postulated above, he will not make any destination human capital investments. Likewise, workers in country $\mathrm{Y}$ will search in both countries and some $\mathrm{Y}$ workers will move to country $\mathrm{X}$. In this circumstance, migration is a two-way street.

The high randomly drawn wage offer that attracted the migrant from country $\mathrm{X}$ to country Y need not persist indefinitely. Since it is a high-wage draw from the distribution of wage offers in country $\mathrm{Y}$, with the passage of time the immigrant can expect to experience a "regression to the mean" in his wages, certainly in terms of real wages if not in nominal wages. ${ }^{2}$ If this is the case, with the passage of time, there is the appearance of "negative" assimilation in terms of earnings.

Given these possibilities, we want to know whether the immigrant would remain in country Y. The immigrant would return to the origin, $\mathrm{X}$, if the subsequently lowered earnings in the destination, $\mathrm{Y}$, are below his best random draw from country $\mathrm{X}$ by an amount sufficient to compensate for the cost of return migration. Some will choose to return to country X; others will remain in the destination, country Y.

The high initial wage offer in the destination country may arise from factors other than random wage draws. For example, it might arise from an unanticipated exogenous increase in demand in the destination labor market for workers with a particular set of skills, perhaps specific to a particular occupation or industry. If so, with the passage of time, as the labor market adjusts, the wages of the immigrants would regress to the mean. Compared to mean wages in the labor market, the relative decline in immigrant wages in these sectors would give the appearance of negative assimilation. ${ }^{3}$ Note that if

\footnotetext{
${ }^{2}$ Even if nominal wages in a particular job do not decline, even in a recession, the nominal earnings a worker receives may decline because of reduced hours worked or following unemployment the worker accepts a new job offer at a lower nominal wage.

${ }^{3}$ Presumably, native-born workers in these sectors also experience an increase in relative earnings to be followed by a regression to the mean As the costs of international migration exceed the costs of intra-national
}

the higher initial wages in the destination of the migrants are due merely to their higher level of ability (or unmeasured dimensions of human capital) their earnings would not decline with duration.

One implication of this model is the propensity for two-way migration and return migration between two countries of equal levels of income and income inequality between which human capital is perfectly transferable. ${ }^{4}$ Another implication of the model is that immigrants initially experience higher earnings than the native-born in the destination, ceteris paribus, with earnings declining toward that of the native-born with duration in the destination. The decline in earnings is not the result of deterioration in skills, but rather a decline in earnings for a given set of skills. We refer to the decline in real earnings with duration as negative assimilation.

Suppose the international job search occurs just after leaving school and before marriage and family formation. Shortly thereafter, getting married and having children occur in both the origin and destination. This "family capital" raises the cost of migration, thereby discouraging it, including return migration by immigrants who have experienced negative assimilation. This would strengthen the argument for negative assimilation.

Alternative hypotheses that would give the appearance of negative assimilation in cross-sectional data would, of course, include (a) that there has been an increase over time in the unmeasured dimensions of the quality of immigrants (newer immigrants are more able); or (b) that the most

migration, immigrants will be more likely than the native born to be located in relative high-wage regions. Hence, the negative assimilation will be a more intense phenomenon for them than for their native-born counterparts.

${ }^{4}$ Two-way international migration does occur. According to their local censuses, in 1996 about 226,000 people born in the United States lived in Canada, and 30,000 Americans and Canadians and 94,000 Americans and Canadians lived in the Irish Republic and Australia, respectively (Sources: 1996 Censuses of Irish Republic, Australia, and Canada). See also Dumont and Lemaitre (2005). 
successful in the destination country are more likely to exit (die, return to the origin, or move elsewhere). It is not obvious why there would have been an increase over time in the unmeasured dimensions of skill or ability. This hypothesis is tested, however, by analyzing immigrant-native earnings differentials over time. If immigrant quality increased over time, the ratio of immigrant to native earnings, holding constant duration of residence in the destination, would be higher in recent data than in earlier data, $c e^{-}$ teris paribus.

It is not obvious why the most successful of the immigrants in the destination country would have a higher propensity to exit from the data. Exit from the data may occur because of death, withdrawal from the labor force, or return migration. There is little analysis on the selectivity, other variables being the same, out of the U.S. labor market of adult male immigrants. Lubotsky (2007) used longitudinal earnings data from U.S. Social Security records to study the effect of selective emigration on the earnings of immigrants. He found selectivity in return migration, with the emigration rate being higher for lower-wage workers. He did not test whether this selectivity also characterized immigrants from English-speaking developed countries. In a matched sample of immigrants in the 1983 and 1995 Censuses of Israel, Beenstock, Chiswick, and Paltiel (2010) found that those who died between 1983 and 1995 had lower earnings in 1983, presumably because they were in poorer health. These researchers also found that there was no difference in 1983 earnings between those who emigrated over the 12-year period and those who were successfully interviewed again in 1995. That is, they found no evidence that among immigrants in Israel the "exits" were positively selected on unmeasured characteristics, other variables being the same. Indeed, within the context of the negative assimilation model, presumably those who experience the steepest regression to the mean, that is, the greatest negative assimilation, would be the most likely to return to their origin. Their exit would reduce the appearance of negative assimilation among those who remain.

\section{The Application to Immigrants}

The model of negative assimilation we have developed has several stringent requirements. Namely, the income levels are the same in both origin and destination countries and skills acquired and required in one country are perfectly transferable to the other. There are, however, no cases of countries in which these conditions are strictly observed.

Language is a particularly important form of country-specific human capital, and skill transferability is greater among the highly developed economies than between developed and less-developed countries or among less-developed countries. Moreover, among developed countries, those with a high degree of cultural similarity, or that share the same cultural origins, are more likely to have similar labor market institutions. This suggests that an appropriate test of the "negative" assimilation hypothesis for international migrants would be among developed countries that possess a common language and culture, and for which the relevant data exists. The closest approximation in the international arena would be migration among the English-speaking developed countries (ESDC), namely the United States, Canada, Ireland, Australia, New Zealand, and the United Kingdom. Immigrants to the United States and Australia born in other Englishspeaking developed countries satisfy these requirements. Moreover, immigrants to Sweden from the other Nordic or Scandinavian countries would also satisfy these criteria.

We performed the main empirical testing of the model of negative assimilation for the United States. Using the 1980, 1990, and 2000 Censuses of Population of the United States (1\% PUMS data in 1980; 5\% in 1990 and 2000), we analyzed adult male immigrants born in Canada, the United Kingdom (U.K.), Ireland, Australia, and New Zealand. ${ }^{5}$ We also

\footnotetext{
${ }^{5}$ An alternative test would be migration among the states of the United States with similar levels of income. The U.S. Census provides information on state of birth, state of residence five years ago, and current state of residence, but this offers too little detail on the timing of inter-state migration.
} 
Table 1. Year of Immigration Data in U.S. Censuses

\begin{tabular}{lcc}
\hline Census & $\begin{array}{c}\text { Number of Categories used for } \\
\text { Year of Immigration Data }\end{array}$ & $\begin{array}{c}\text { Year of Immigration } \\
\text { Information }\end{array}$ \\
\hline 1980 & 6 & $1975-1980 ; 1970-1974 ; 1965-1969 ; 1960-1964 ;$ \\
& & $1950-1959 ;$ Before 1950. \\
1990 & 10 & $1987-1990 ; 1985-1986 ; 1982-1984 ; 1980-1981 ;$ \\
& & $1975-1979 ; 1970-1974 ; 1965-1969 ; 1960-1964 ;$ \\
2000 & In single years & $1950-1959 ;$ Before 1950. \\
\hline
\end{tabular}

Source: 1980, 1990, and 2000 U.S. Censuses of Population.

performed empirical tests for Australia using the data on the ESDC in the 2001 Census of Australia. We also report findings on immigrant adjustment in Sweden, comparing Nordic and other E.U. immigrants.

\section{United States}

The estimating equation for the United States regresses the natural logarithm of annual earnings in the year prior to the U.S. Census among adult (aged 25-64) male immigrants from the other English-speaking developed countries on the following characteristics: years of education, years of labor market experience (measured by age minus years of education minus six), and its square, whether the respondent is currently married (spouse present), the natural logarithm of weeks worked in the reference year, whether a language other than English is spoken by the respondent at home, and, if so, his English language proficiency, and urban/rural and region control variables. ${ }^{6}$ The immigration variables include years since migration (YSM) to the United States and country-oforigin dichotomous variables. We provide brief descriptions of all variables in Appen$\operatorname{dix} \mathrm{A}$. If the negative assimilation hypothesis is to be supported by the data, the coefficient on years since migration would have a negative sign. To test for cohort effects-if the unmeasured dimensions of immigrant

\footnotetext{
${ }^{6}$ The language variable is included in large part because of French Canadians. It is not possible to distinguish immigrants from Quebec from other Canadian immigrants in the U.S. Census, other than through their speaking French at home.
}

quality have increased over time-the ratio of immigrant to native earnings, ceteris paribus, would be higher in 2000 than in the earlier Census data. We computed separate analyses for the United States by country of origin among the ESDC to ascertain whether the negative assimilation effects are dominated by one origin, or if they are broadbased among the ESDC origins.

The crucial variable for this analysis is the year of immigration. The detail on this in the public use samples for the Censuses in the United States has changed over time. As Table 1 shows, progressively more detail has been presented over time on the year of immigration, with single years being used in $2000 .^{7}$ We followed the literature (e.g., Chiswick 1978) and formed a continuous variable by using the mid-points of the period of immigration categories for analyses of the 1980 and 1990 Census data. We computed duration in the United States as the Census year minus the year of immigration.

Appendix Table A1 reports the means and standard deviations for the natural logarithm of earnings and for the explanatory variables. There is a pronounced increase, by nearly one log point, in the natural logarithm of earnings between 1980 and 2000. That is, nominal earnings more than doubled among ESDC immigrants and real earnings increased by about $1.3 \%$ per year. ${ }^{8}$

\footnotetext{
${ }^{7}$ Note, however, that this information is self-reported, and there is bunching in the data around the years ending in zero or five.

${ }^{8}$ The mean of the natural logarithm of earnings (the geometric mean) increased by $0.994 \log$ points, from
} 
Table 2. Percent of Adult Male Immigrants from ESDC in the U.S. by English Proficiency and the Top Five Non-English Languages, by Country of Origin, 2000

\begin{tabular}{|c|c|c|c|c|}
\hline \multirow[b]{2}{*}{ Group } & \multirow{2}{*}{$\begin{array}{c}\% \text { English } \\
\text { Only }\end{array}$} & \multicolumn{2}{|c|}{$\begin{array}{c}\text { Speaks Another Language } \\
\text { or Speaks English }\end{array}$} & \multirow{2}{*}{$\begin{array}{c}\text { Top } 5 \text { Languages Spoken } \\
(\% \text { speaking them })\end{array}$} \\
\hline & & Very Well/Well & Not Well/Not at All & \\
\hline Total & 85.8 & 13.4 & 0.7 & $\begin{array}{l}\text { French (6.60); Spanish (1.18); Irish Gaelic } \\
\text { (0.96); German/Austrian/Swiss (0.73); } \\
\text { Italian }(0.59)\end{array}$ \\
\hline $\begin{array}{l}\text { United } \\
\text { Kingdom }\end{array}$ & 90.7 & 8.8 & 0.6 & $\begin{array}{l}\text { French (2.23); Spanish (1.07); German/ } \\
\text { Austrian/Swiss (0.53); Gujarathi }(0.41) \text {; } \\
\text { Polish (0.37). }\end{array}$ \\
\hline Ireland & 86.2 & 12.9 & 0.9 & $\begin{array}{l}\text { Irish Gaelic (9.39); French (1.35); Spanish } \\
(1.27) ; \text { German/Austrian/Swiss }(0.36) ; \\
\text { Italian }(0.25)\end{array}$ \\
\hline Canada & 80.6 & 18.5 & 0.9 & $\begin{array}{l}\text { French (12.64); Spanish (1.22); German/ } \\
\text { Austrian/Swiss (1.02); Italian }(0.80) \text {; } \\
\text { Greek }(0.52)\end{array}$ \\
\hline $\begin{array}{l}\text { Australia } \\
\text { \& N.Z. }\end{array}$ & 90.5 & 9.0 & 0.5 & $\begin{array}{l}\text { Greek (1.54); Spanish (1.43); Italian (1.10); } \\
\text { French }(0.70) \text {; German/Austrian/ } \\
\text { Swiss }(0.51) .\end{array}$ \\
\hline
\end{tabular}

Source: U.S. Census of Population: 2000 PUMS, 5\% sample.

The mean educational attainment (15.2 years in 2000) increased by 0.7 years over the 20-year period analyzed. Immigrants from ESDC in the 2000 data have resided in the United States for about the same length of time as those in 1980 ( 19.5 years).

Slightly more than $14 \%$ of the sample of immigrants from ESDC in the United States reported speaking a language other than or in addition to English at home in the 2000 Census, and about $12 \%$ did so in each of the earlier data sets (see Table 2). The importance of Irish Gaelic among immigrants from Ireland, and French among immigrants from Canada, is shown in Table 2. Separate analyses are conducted for "French" Canadians, defined here as immigrants from Canada who speak French at home, and other Canadians. Due to small sample sizes, how-

9.731 in 1980 to 10.725 in 2000 . This increase implies more than a doubling of nominal earnings $\left(\mathrm{e}^{* *} 0.994\right.$ $=2.702$ ). The Consumer Price Index increased from 100.0 in 1980 to 208.5 in 2000, implying that the log of prices increased by $0.735(\ln 2.0850=0.735)$. The $\log$ of real earnings, therefore, increased over the 20-year period by a difference of 0.259 , or at an annual rate of about $1.3 \%\left(0.259 / 20=0.01295\right.$ and $\mathrm{e}^{* *} 0.01295=$ $1.013)$. ever, we have not given further consideration to those immigrants speaking Irish Gaelic at home in the United States.

Table 3 reports the estimated earnings functions for adult male immigrants from the advanced English-speaking developed countries. ${ }^{9}$ These analyses are based on two specifications of the earnings equation: the first contains a quadratic in years since migration (YSM) and the second uses only a linear variable for YSM. The standard model of immigrant labor market adjustment"positive" assimilation-implies a quadratic specification for years since migration. The negative assimilation model hypothesizes a negative sign but does not indicate whether a linear or a quadratic specification is preferred. Both specifications are applied here.

\footnotetext{
${ }^{9}$ There is little research on the earnings of immigrants among the English-speaking developed countries. Lindner (1989) developed a joint emigration-earnings model for emigrants from the United States to Canada. Card (2003) considered Canadian emigrants in the United States, focusing on their educational attainment. Both studies found favorable selectivity among the migrants. Neither study reported on the effect of duration in the destination on the earnings of the immigrants or on the selectivity of return migrants.
} 
Table 3. Analyses of Immigrant Earnings, 25 to 64-Year-Old Male Immigrants from English-Speaking Developed Countries, 1980, 1990 and 2000 U.S. Censuses ${ }^{\mathrm{a}}$

\begin{tabular}{|c|c|c|c|c|c|c|}
\hline \multirow{3}{*}{$\frac{\text { Variable }^{\mathrm{b}}}{\text { Constant }}$} & \multicolumn{2}{|c|}{1980} & \multicolumn{2}{|c|}{1990} & \multicolumn{2}{|c|}{2000} \\
\hline & 3.601 & 3.630 & 4.252 & 4.271 & 4.526 & 4.525 \\
\hline & $(13.43)$ & $(13.51)$ & $(33.84)$ & $(34.04)$ & $(35.70)$ & $(35.67)$ \\
\hline \multirow[t]{2}{*}{ Educational Attainment } & 0.064 & 0.064 & 0.077 & 0.077 & 0.104 & 0.104 \\
\hline & $(12.27)$ & $(12.28)$ & $(28.83)$ & $(28.85)$ & $(42.36)$ & $(42.42)$ \\
\hline \multirow[t]{2}{*}{ Experience (EXP) } & 0.058 & 0.059 & 0.047 & 0.047 & 0.048 & 0.048 \\
\hline & $(10.80)$ & $(11.14)$ & $(19.19)$ & $(19.49)$ & $(19.17)$ & $(19.21)$ \\
\hline \multirow{2}{*}{$\mathrm{EXP}^{2} / 100$} & -0.094 & -0.096 & -0.073 & -0.074 & -0.074 & -0.074 \\
\hline & $(9.06)$ & $(9.48)$ & $(14.33)$ & $(14.65)$ & $(14.82)$ & $(14.91)$ \\
\hline \multirow{2}{*}{ Years Since Migration (YSM) } & 0.002 & -0.003 & -0.000 & -0.004 & -0.007 & -0.007 \\
\hline & $(0.49)$ & $(2.11)$ & $(0.26)$ & $(6.29)$ & $(4.31)$ & $(13.42)$ \\
\hline \multirow{2}{*}{$\mathrm{YSM}^{2} / 100$} & -0.011 & $*$ & -0.007 & $*$ & 0.000 & $*$ \\
\hline & $(1.15)$ & & $(2.06)$ & & $(0.09)$ & \\
\hline \multirow[t]{2}{*}{ Log Weeks Worked } & 1.151 & 1.154 & 1.129 & 1.131 & 0.975 & 0.975 \\
\hline & (16.84) & (16.93) & $(36.02)$ & (36.13) & $(33.56)$ & $(33.62)$ \\
\hline \multirow[t]{2}{*}{ Married } & 0.256 & 0.255 & 0.244 & 0.243 & 0.256 & 0.256 \\
\hline & $(6.49)$ & $(6.46)$ & $(16.52)$ & $(16.46)$ & (19.42) & $(19.43)$ \\
\hline \multirow[t]{2}{*}{ South } & -0.173 & -0.175 & -0.133 & -0.134 & -0.069 & -0.069 \\
\hline & $(4.23)$ & $(4.29)$ & $(8.34)$ & $(8.38)$ & $(5.15)$ & $(5.16)$ \\
\hline \multirow[t]{2}{*}{$\operatorname{Rural}^{(c)}$} & -0.046 & -0.048 & -0.102 & -0.102 & -0.295 & -0.295 \\
\hline & $(0.74)$ & $(0.78)$ & $(5.22)$ & $(5.21)$ & $(6.16)$ & $(6.16)$ \\
\hline \multirow[t]{2}{*}{ English Very Well/Well } & -0.107 & -0.107 & -0.073 & -0.072 & -0.029 & -0.029 \\
\hline & $(2.29)$ & $(2.29)$ & $(3.29)$ & $(3.26)$ & $(1.66)$ & $(1.66)$ \\
\hline \multirow[t]{2}{*}{ English Not Well/Not at All } & -0.135 & -0.131 & -0.041 & -0.041 & 0.074 & 0.074 \\
\hline & $(0.52)$ & $(0.50)$ & $(0.47)$ & $(0.47)$ & $(0.94)$ & $(0.94)$ \\
\hline \multirow[t]{2}{*}{ Ireland } & -0.092 & -0.086 & 0.003 & 0.002 & -0.003 & -0.003 \\
\hline & (1.92) & $(1.81)$ & $(0.17)$ & $(0.13)$ & $(0.14)$ & $(0.14)$ \\
\hline \multirow[t]{2}{*}{ Canada } & 0.015 & 0.016 & -0.011 & -0.011 & -0.007 & -0.007 \\
\hline & $(0.49)$ & $(0.54)$ & $(0.79)$ & $(0.77)$ & $(0.53)$ & $(0.53)$ \\
\hline \multirow[t]{2}{*}{ Australia \& New Zealand } & -0.074 & -0.084 & -0.062 & -0.065 & -0.007 & -0.007 \\
\hline & $(0.90)$ & $(1.03)$ & $(1.47)$ & $(1.55)$ & $(0.26)$ & $(0.25)$ \\
\hline $\bar{R}^{2}$ & 0.3289 & 0.3288 & 0.3061 & 0.3060 & 0.2707 & 0.2707 \\
\hline Sample Size & 3,480 & 3,480 & 18,046 & 18,046 & 21,777 & 21,777 \\
\hline
\end{tabular}

a Absolute value of heteroskedasticity-consistent t-statistics in parentheses.

${ }^{\mathrm{b}}$ Asterisk indicates variable not entered.

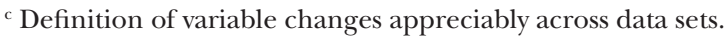

Sources: U.S. Censuses of Population: 1980 1\% PUMS; 1990 5\% PUMS; 2000 5\% PUMS.

The estimates reported in Table 3 possess all the characteristics of recent research on immigrant earnings, and in particular the steady increase over time for immigrants in the payoff to schooling (from $6.4 \%$ in 1980 to $10.4 \%$ in 2000 ), the decline in the elasticity of earnings with respect to weeks worked (from 1.15 to around unity), and the decline in the North-South earnings differential. ${ }^{10}$

\footnotetext{
${ }^{10}$ When dichotomous variables are included in the immigrant and the pooled immigrant and native-born
}

Other than marginally significant lower earnings among immigrants from Ireland in 1980 , other variables being the same, earnings do not differ significantly from the benchmark, the United Kingdom, across the immigrant groups identified in the analysis.

Earnings are significantly lower among those who report that in addition to English

equations for persons who are Black, the changes in the relevant coefficients are trivial. There is no effect on the interpretation of negative assimilation. 
they speak another language at home, but that they speak English very well or well. ${ }^{11}$ This negative effect declines from $11 \%$ in 1980 to $7 \%$ in 1990 to a marginally significant $3 \%$ in 2000 . This effect seems to arise primarily from the earnings disadvantage of French-speaking Canadians diminishing over time. The statistically insignificant effect on earnings of speaking English not well or not at all appears to be due to the trivial size of the sample.

The estimates for the variables for duration in the United States (YSM) support the negative assimilation hypothesis. In 1980, neither the linear nor the squared YSM terms were statistically significant when a quadratic YSM specification was used. When only a linear duration variable was employed the statistically significant $(t=-2.11)$ coefficient of -0.003 indicated a decline of earnings at 0.3 of one percentage point per year in the United States.

In the 1990 data, when a quadratic YSM specification was used, both coefficients were negative, but only that for the squared variable was statistically significant. When a linear specification was used the statistically significant $(\mathrm{t}=-6.29)$ estimated coefficient of -0.004 indicated a decline of earnings at 0.4 of one percentage point per year.

For the 2000 data, the quadratic specification showed that the YSM variable had a significant negative coefficient, but the squared YSM term was not significant. The linear specification resulted in a highly significant $(\mathrm{t}=-13.42)$ negative coefficient on the duration variable, -0.007 . That is, there is decline in ESDC immigrant earnings at the rate of 0.7 of one percentage point per year of duration in the United States. ${ }^{12}$ Thus, these results from analyses of the 1980, 1990 and 2000 U.S. Censuses

\footnotetext{
11 The significant negative assimilation effect is essentially unchanged if these language variables are deleted from the equation (to see these results, Appendix Table $\mathrm{B} 5$, not shown here, is available on request by writing to the authors).

12 This does not imply a decrease in real earnings. The change in real earnings will be given by the sum of the impacts of labor market experience and years since migration.
}

indicate strong support for the negative assimilation hypothesis. ${ }^{13}$

The Table 3 results also indicate that the negative assimilation effect has intensified over time. The strengthening of this effect could be an economic phenomenon or the result of the change in the detail on year of immigration used in the analysis (see Table $1)$. To ascertain whether the latter is important, the year of immigration data in the 2000 Census were first recoded into ten categories analogous to those available for the 1990 data, and an alternative YSM variable was created using the mid-points of these categories. The earnings equation using this alternative variable resulted in an estimate of the negative assimilation effect for 2000 of -0.006 (t-ratio $=-13.15$ ), instead of the -0.007 (t-ratio $=-13.42$ ) using the full detail. ${ }^{14}$ This effect shows that the presentation of the YSM data is of modest importance for the statistical analyses undertaken here. Moreover, this apparent slight diminution of the estimated impact of the duration variable when less detailed categorical information is used strengthens the evidence in support of the negative assimilation hypothesis. It indicates that the effects estimated for 1980 and 1990 are biased somewhat toward zero by the use of the less detailed categorical information on years since migration.

Under the negative assimilation hypothesis, the initial high U.S. labor market entry wage is driven by a favorable draw from the distribution of wage offers. In this situation, the negative relationship between earnings and duration of residence should be less intense, or even non-existent, among immigrants who arrived in the United States as

\footnotetext{
${ }^{13}$ In an analysis of annual hours of work among immigrants using the 1980, 1990, and 2000 Censuses, Blau, Kahn, and Papps (2011) found hours worked by immigrants from English-speaking countries or those for which English is an official language was flatter with duration of residence in the United States compared to other immigrants. This is consistent with the negative assimilation hypothesis.

${ }^{14}$ The 2000 Census year of immigration data were also recoded to six categories analogous to those available for the 1980 data, and a similar analysis that was undertaken. The estimate of the negative assimilation effect was -0.006 (t-ratio $=-12.58)$.
} 
Table 4. Selected Estimates of Earnings Functions for Immigrants Arriving as Adults and as Children, 25 to 64-Year-Old Male Immigrants from English-Speaking Developed Countries, 2000 U.S. Census ${ }^{\mathrm{a}}$

\begin{tabular}{|c|c|c|c|c|c|c|}
\hline \multirow[b]{2}{*}{$\begin{array}{c}\text { Arrival Age } \\
\text { Threshold for Adults }\end{array}$} & \multicolumn{3}{|c|}{ Arrived as Children } & \multicolumn{3}{|c|}{ Arrived as Adults } \\
\hline & $\begin{array}{l}\text { Educational } \\
\text { Attainment }\end{array}$ & $Y S M$ & Sample Size & $\begin{array}{l}\text { Educational } \\
\text { Attainment }\end{array}$ & $Y S M$ & Sample Size \\
\hline $12+$ & $\begin{array}{r}0.111 \\
(17.15)\end{array}$ & $\begin{array}{c}-0.003 \\
(0.88)\end{array}$ & 5,429 & $\begin{array}{r}0.102 \\
(35.84)\end{array}$ & $\begin{array}{r}-0.007 \\
(7.78)\end{array}$ & 16,348 \\
\hline $13+$ & $\begin{array}{r}0.109 \\
(18.06)\end{array}$ & $\begin{array}{r}-0.002 \\
(0.69)\end{array}$ & 5,696 & $\begin{array}{r}0.101 \\
(35.32)\end{array}$ & $\begin{array}{c}-0.006 \\
(7.25)\end{array}$ & 16,081 \\
\hline $14+$ & $\begin{array}{r}0.108 \\
(18.42)\end{array}$ & $\begin{array}{c}-0.004 \\
(1.23)\end{array}$ & 5,943 & $\begin{array}{r}0.102 \\
(35.11)\end{array}$ & $\begin{array}{c}-0.006 \\
(7.11)\end{array}$ & 15,874 \\
\hline $15+$ & $\begin{array}{r}0.108 \\
(19.17)\end{array}$ & $\begin{array}{c}-0.005 \\
(1.99)\end{array}$ & 6,188 & $\begin{array}{r}0.102 \\
(34.88)\end{array}$ & $\begin{array}{r}-0.007 \\
(7.05)\end{array}$ & 15,589 \\
\hline $16+$ & $\begin{array}{r}0.107 \\
(19.62)\end{array}$ & $\begin{array}{c}-0.005 \\
(2.07)\end{array}$ & 6,475 & $\begin{array}{r}0.102 \\
(34.43)\end{array}$ & $\begin{array}{r}-0.007 \\
(6.68)\end{array}$ & 15,302 \\
\hline $17+$ & $\begin{array}{c}0.105 \\
(20.09)\end{array}$ & $\begin{array}{c}-0.004 \\
(2.02)\end{array}$ & 6,759 & $\begin{array}{c}0.102 \\
(33.90)\end{array}$ & $\begin{array}{c}-0.006 \\
(6.31)\end{array}$ & 15,018 \\
\hline $18+$ & $\begin{array}{r}0.106 \\
(20.97)\end{array}$ & $\begin{array}{c}-0.005 \\
(2.59)\end{array}$ & 7,085 & $\begin{array}{r}0.102 \\
(33.30)\end{array}$ & $\begin{array}{c}-0.006 \\
(6.00)\end{array}$ & 14,692 \\
\hline
\end{tabular}

a Absolute value of heteroskedasticity-consistent t-statistics in parentheses.

Notes: The estimating equation also holds constant labor market experience and its square, log of weeks worked, whether currently married (spouse present), whether the respondent lives in the South or a rural (1980, 1990) or non-metropolitan (2000) area, proficiency in English if a language other than English is spoken at home, and country of origin dichotomous variables (U.K. as benchmark).

Source: U.S. Census of Population: 2000 5\% PUMS.

children-they will be tied movers. The relationship between earnings and years since migration could still be negative for immigrants who arrived as children if the high wage draw for their parents is partly a reflection of initial settlement in a tight labor market, and this results in a favorable initial wage offer for the foreign-born children of immigrants. However, this influence should be weaker the younger the age at migration.

To assess this influence, we estimated separate earnings equations for immigrants who arrived in the United States as children and those who arrived as adults. A difficulty with this approach is that an age at migration has to be inferred from the Census self-reports on current age and year of arrival in the United States. The bunching in the data on year of arrival (at years ending in 5 and, particularly, zero) suggests that separating groups that arrived as adults and as children will be imprecise. Consideration is therefore given to a number of ages of arrival as the adult-children threshold, with most empha- sis placed on the broad patterns that emerge from this analysis.

Table 4 lists selected findings from this analysis by age at migration. This exercise is reported only for the 2000 Census data because of the greater detail on year of arrival and for simplicity using only the linear specification of the duration variable. The coefficients on educational attainment and duration are listed for selected adult-children thresholds, together with the sample sizes.

The results in Table 4 for the adult samples are similar for each threshold age and similar to the results in Table 3: the payoff to education is a little more than $10 \%$, and the coefficient on the YSM variable is between -0.006 and -0.007 , with both coefficients highly statistically significant. Among the samples of adults who immigrated as children, the payoff to education is similar to that of adults (11\% compared to $10 \%)$ and the coefficient on the YSM variable is smaller in absolute value. The similar coefficient on schooling for the adult immigrants 
compared to the child immigrants is consistent with the ESDC immigrants entering with a high degree of skill transferability and relatively low costs of immigration (Chiswick and Miller 2008a). ${ }^{15}$

The coefficient on duration is negative in all of the equations in Table 4 among adult immigrants; its magnitude is similar to that in Table 3 and is highly statistically significant. Among the child immigrants, however, the magnitude is smaller, decreases, and becomes statistically insignificant as older children are excluded. Indeed, the coefficient is not significant in the samples of young children formed using age at arrival of 14 or younger. Nevertheless, the differences in the coefficients on the duration variable between adult and child immigrants are not statistically significant, and the point estimates for the child immigrants support the negative assimilation hypothesis.

Table 5 presents estimates of the payoff to schooling and the estimated coefficients for the duration variables from the separate analyses undertaken for immigrants from the United Kingdom, Ireland, Canada and Australia/New Zealand. ${ }^{16}$ For the United Kingdom and Canada, where sample sizes are relatively large, the negative assimilation effect is alive and well, and there is evidence for it increasing over time. A similar pattern is evident for the much smaller samples of immigrants from Australia and New Zealand. In the somewhat larger sample for Australia and New Zealand in $2000(1,250$ observations), the coefficient on duration in the quadratic specification is negative and significant, and in the linear specification it is negative, although not statistically significant.

The results for Ireland appear to be different from those of the United Kingdom,

\footnotetext{
${ }^{15}$ Among adult native-born males, the schooling coefficient is about $10.6 \%$ and for the foreign-born males as a whole it is about $5.2 \%$ in the 2000 Census (Chiswick and Miller 2008a).

${ }^{16}$ The means and standard deviations of the variables for the separate ESDC immigrants are presented in Appendix Tables A2 to A5. The full regression equations are presented in Appendix B, not shown here. They are available upon request by emailing the authors.
}

Canada and Australia/New Zealand. In the quadratic specification, the coefficient on the duration term is positive and the squared term is negative, and both are at the margin of being statistically significant in 1990. The coefficients in the quadratic specification indicate a positive effect of duration on earnings, which diminishes with duration and eventually becomes negative (after 28 years in the 1990 data). In the linear specification for Ireland, the coefficients of the duration variable have mixed signs and they are not statistically significant. The lower level of income in Ireland, and the ease (low cost) of migration to the United Kingdom, as distinct from migration to the United States, may be responsible for this effect.

Two further sets of analyses were undertaken to test the robustness of the findings for the United States with respect to the language variable. In the first, the variables for proficiency in the English language were omitted from the specification. It has been shown that English proficiency among immigrants is strongly linked to duration of residence, and the inclusion of the language proficiency variable in the earnings equation could distort measurement of the assimilation effect. Table 6 presents the findings for the duration of residence variables from this set of analyses. These estimates mirror those from the earnings function that included the English proficiency variables (compare Table 6 with Tables 3 and 5). The language variable is therefore of little consequence for the quantification of the negative assimilation effect. This is not surprising given that all of the immigrants under study reported that they were born in an English-speaking developed country.

In the second experiment, the data for immigrants born in Canada for 2000 were analyzed separately according to whether the immigrants were French Canadians (defined as speaking French in their home in the United States) or other Canadians. Using the 2000 Census for each sample, the estimate of the assimilation effect was a highly significant -0.006 , where the t-ratios were $\mathrm{t}=-2.61$ for French Canadians and $t=-7.91$ for other Canadians. This estimate was not sensitive to whether information on 
Table 5. Selected Estimates of Immigrant Adjustment Earnings Function, 25 to 64-Year-Old Male Immigrants by Country of Origin, 1980, 1990 and 2000 U.S. Censuses ${ }^{\text {a }}{ }^{b}$

\begin{tabular}{|c|c|c|c|c|c|c|}
\hline Variable $^{\mathrm{c}}$ & \multicolumn{2}{|c|}{1980} & \multicolumn{2}{|c|}{1990} & \multicolumn{2}{|c|}{2000} \\
\hline \multicolumn{7}{|c|}{ United Kingdom: Sample Sizes 1980: 1,268; 1990: 7,439; 2000: 8,917 } \\
\hline Educational Attainment & $\begin{array}{r}0.077 \\
(8.68)\end{array}$ & $\begin{array}{r}0.077 \\
(8.67)\end{array}$ & $\begin{array}{r}0.085 \\
(20.15)\end{array}$ & $\begin{array}{c}0.085 \\
(20.19)\end{array}$ & $\begin{array}{c}0.109 \\
(28.08)\end{array}$ & $\begin{array}{r}0.109 \\
(28.09)\end{array}$ \\
\hline Years Since Migration (YSM) & $\begin{array}{c}-0.004 \\
(0.64)\end{array}$ & $\begin{array}{r}-0.002 \\
(1.18)\end{array}$ & $\begin{array}{r}-0.002 \\
(0.88)\end{array}$ & $\begin{array}{c}-0.005 \\
(5.35)\end{array}$ & $\begin{array}{c}-0.009 \\
(3.68)\end{array}$ & $\begin{array}{c}-0.009 \\
(11.01)\end{array}$ \\
\hline $\mathrm{YSM}^{2} / 100$ & $\begin{array}{c}0.005 \\
(0.35)\end{array}$ & $*$ & $\begin{array}{c}-0.005 \\
(0.93)\end{array}$ & $*$ & $\begin{array}{c}0.002 \\
(0.38)\end{array}$ & $*$ \\
\hline \multicolumn{7}{|c|}{ Ireland: Sample Sizes 1980: 367; 1990: 1,857; 2000: 2,029 } \\
\hline Educational Attainment & $\begin{array}{c}0.022 \\
(1.50)\end{array}$ & $\begin{array}{c}0.020 \\
(1.37)\end{array}$ & $\begin{array}{c}0.051 \\
(7.51)\end{array}$ & $\begin{array}{r}0.051 \\
(7.48)\end{array}$ & $\begin{array}{c}0.072 \\
(9.26)\end{array}$ & $\begin{array}{r}0.072 \\
(9.24)\end{array}$ \\
\hline Years Since Migration (YSM) & $\begin{array}{r}0.027 \\
(1.58)\end{array}$ & $\begin{array}{c}0.004 \\
(0.70)\end{array}$ & $\begin{array}{c}0.010 \\
(2.01)\end{array}$ & $\begin{array}{c}0.002 \\
(0.89)\end{array}$ & $\begin{array}{c}0.008 \\
(1.40)\end{array}$ & $\begin{array}{r}-0.001 \\
(0.67)\end{array}$ \\
\hline $\mathrm{YSM}^{2} / 100$ & $\begin{array}{c}-0.046 \\
(1.33)\end{array}$ & $*$ & $\begin{array}{c}-0.018 \\
(1.95)\end{array}$ & $*$ & $\begin{array}{c}-0.020 \\
(1.77)\end{array}$ & $*$ \\
\hline \multicolumn{7}{|c|}{ Canada: Sample Sizes 1980: 1,733; 1990: 7,956; 2000: 9,581 } \\
\hline Educational Attainment & $\begin{array}{c}0.065 \\
(8.96)\end{array}$ & $\begin{array}{c}0.064 \\
(9.08)\end{array}$ & $\begin{array}{r}0.077 \\
(18.31)\end{array}$ & $\begin{array}{r}0.076 \\
(18.25)\end{array}$ & $\begin{array}{r}0.108 \\
(28.74)\end{array}$ & $\begin{array}{r}0.108 \\
(28.87)\end{array}$ \\
\hline Years Since Migration (YSM) & $\begin{array}{c}0.002 \\
(0.27)\end{array}$ & $\begin{array}{c}-0.004 \\
(1.99)\end{array}$ & $\begin{array}{c}0.001 \\
(0.32)\end{array}$ & $\begin{array}{c}-0.004 \\
(4.19)\end{array}$ & $\begin{array}{c}-0.004 \\
(2.00)\end{array}$ & $\begin{array}{r}-0.006 \\
(8.12)\end{array}$ \\
\hline $\mathrm{YSM}^{2} / 100$ & $\begin{array}{c}-0.014 \\
(0.89)\end{array}$ & * & $\begin{array}{c}-0.009 \\
(1.87)\end{array}$ & $*$ & $\begin{array}{c}-0.003 \\
(0.57)\end{array}$ & $*$ \\
\hline \multicolumn{7}{|c|}{ Australia and New Zealand: Sample Sizes 1980: 112; 1990: 794; 2000: 1,250 } \\
\hline Educational Attainment & $\begin{array}{r}0.070 \\
(2.14)\end{array}$ & $\begin{array}{c}0.069 \\
(2.21)\end{array}$ & $\begin{array}{c}0.091 \\
(6.53)\end{array}$ & $\begin{array}{r}0.091 \\
(6.52)\end{array}$ & $\begin{array}{c}0.104 \\
(11.14)\end{array}$ & $\begin{array}{r}0.103 \\
(11.08)\end{array}$ \\
\hline Years Since Migration (YSM) & $\begin{array}{c}-0.011 \\
(0.35)\end{array}$ & $\begin{array}{c}-0.003 \\
(0.55)\end{array}$ & $\begin{array}{r}-0.000 \\
(0.03)\end{array}$ & $\begin{array}{c}-0.000 \\
(0.11)\end{array}$ & $\begin{array}{c}-0.014 \\
(2.21)\end{array}$ & $\begin{array}{r}-0.004 \\
(1.42)\end{array}$ \\
\hline $\mathrm{YSM}^{2} / 100$ & $\begin{array}{c}0.018 \\
(0.25)\end{array}$ & $*$ & $\begin{array}{c}-0.000 \\
(0.02)\end{array}$ & $*$ & $\begin{array}{c}0.026 \\
(1.71)\end{array}$ & $*$ \\
\hline
\end{tabular}

${ }^{\text {a }}$ Full set of results available upon request by emailing the authors.

${ }^{\mathrm{b}}$ Absolute value of heteroskedasticity-consistent t-statistics in parentheses.

${ }^{c}$ Asterisk indicates variable not entered.

Notes: The estimating equation also holds constant labor market experience and its square, $\log$ of weeks worked, whether currently married (spouse present), whether the respondent lives in the South or a rural $(1980,1990)$ or non-metropolitan (2000) area, proficiency in English if a language other than English is spoken at home, and country of origin dichotomous variables (U.K. as benchmark).

Sources: U.S. Censuses of Population: 1980 1\% PUMS; 1990 5\% PUMS; 2000 5\% PUMS.

the degree of proficiency in English was included in the model. Hence, the negative assimilation effect observed for immigrants from Canada appears to be independent of whether they also speak French at home.

\section{Australia}

Further evidence regarding the negative assimilation effect among immigrants in the ESDC from other English-speaking countries is provided in a recent study of immigrant earnings in Australia (Chiswick and
Miller 2008b, Table 7). ${ }^{17}$ Using the Australian 2001 Census data for adult foreign-born men, other variables being the same, earnings increased with duration in Australia among those who were not born in the ESDC. Among those born in the ESDC, however, earnings decreased with duration, other variables being the same.

${ }^{17}$ In the analysis for Australia, the ESDC include the United States, Canada, the United Kingdom, Ireland, and New Zealand. 
Table 6. Selected Estimates of Immigrant Adjustment Earnings Function, 25 to 64-Year-Old Male Immigrants by Country of Origin, Without Language Variables, 1980, 1990 and 2000 U.S. Censuses ${ }^{\mathrm{a}, \mathrm{b}}$

\begin{tabular}{|c|c|c|c|c|c|c|}
\hline \multirow{2}{*}{ Variable $^{c}$} & \multicolumn{2}{|c|}{1980} & \multicolumn{2}{|c|}{1990} & \multicolumn{2}{|c|}{2000} \\
\hline & 3,$480 ; 199$ &, $046 ; 200$ & 777 & & & \\
\hline Years Since Migration (YSM) & $\begin{array}{c}0.003 \\
(0.54)\end{array}$ & $\begin{array}{c}-0.003 \\
(1.90)\end{array}$ & $\begin{array}{c}-0.000 \\
(0.28)\end{array}$ & $\begin{array}{c}-0.004 \\
(6.17)\end{array}$ & $\begin{array}{c}-0.007 \\
(4.36)\end{array}$ & $\begin{array}{c}-0.007 \\
(13.41)\end{array}$ \\
\hline $\mathrm{YSM}^{2} / 100$ & $\begin{array}{c}-0.011 \\
(1.15)\end{array}$ & $*$ & $\begin{array}{r}-0.007 \\
(1.99)\end{array}$ & $*$ & $\begin{array}{c}0.001 \\
(0.15)\end{array}$ & * \\
\hline \multicolumn{7}{|c|}{ United Kingdom: Sample Sizes 1980: 1,268; 1990: 7,439; 2000: 8,917 } \\
\hline Years Since Migration (YSM) & $\begin{array}{c}-0.004 \\
(0.59)\end{array}$ & $\begin{array}{c}-0.002 \\
(1.05)\end{array}$ & $\begin{array}{c}-0.002 \\
(0.85)\end{array}$ & $\begin{array}{c}-0.005 \\
(5.35)\end{array}$ & $\begin{array}{c}-0.010 \\
(3.70)\end{array}$ & $\begin{array}{c}-0.009 \\
(11.00)\end{array}$ \\
\hline $\mathrm{YSM}^{2} / 100$ & $\begin{array}{c}0.005 \\
(0.33)\end{array}$ & $*$ & $\begin{array}{c}-0.005 \\
(0.96)\end{array}$ & $*$ & $\begin{array}{c}0.002 \\
(0.40)\end{array}$ & $*$ \\
\hline \multicolumn{7}{|c|}{ Ireland: Sample Sizes 1980: 367; 1990: 1,857; 2000: 2,029 } \\
\hline Years Since Migration (YSM) & $\begin{array}{c}0.026 \\
(1.54)\end{array}$ & $\begin{array}{c}0.004 \\
(0.68)\end{array}$ & $\begin{array}{r}0.010 \\
(2.09)\end{array}$ & $\begin{array}{c}0.002 \\
(1.03)\end{array}$ & $\begin{array}{c}0.008 \\
(1.42)\end{array}$ & $\begin{array}{r}-0.001 \\
(0.61)\end{array}$ \\
\hline $\mathrm{YSM}^{2} / 100$ & $\begin{array}{c}-0.045 \\
(1.30)\end{array}$ & $*$ & $\begin{array}{c}-0.018 \\
(1.99)\end{array}$ & $*$ & $\begin{array}{c}-0.020 \\
(1.76)\end{array}$ & $*$ \\
\hline \multicolumn{7}{|c|}{ Canada: Sample Sizes 1980: 1,733; 1990: 7,956; 2000: 9,581 } \\
\hline Years Since Migration (YSM) & $\begin{array}{c}0.003 \\
(0.37)\end{array}$ & $\begin{array}{c}-0.004 \\
(1.76)\end{array}$ & $\begin{array}{r}0.001 \\
(0.31)\end{array}$ & $\begin{array}{c}-0.004 \\
(4.12)\end{array}$ & $\begin{array}{c}-0.004 \\
(1.94)\end{array}$ & $\begin{array}{r}-0.006 \\
(8.18)\end{array}$ \\
\hline $\mathrm{YSM}^{2} / 100$ & $\begin{array}{c}-0.015 \\
(0.93)\end{array}$ & $*$ & $\begin{array}{c}-0.009 \\
(1.84)\end{array}$ & $*$ & $\begin{array}{c}-0.003 \\
(0.65)\end{array}$ & $*$ \\
\hline \multicolumn{7}{|c|}{ Australia and New Zealand: Sample Sizes 1980: 112; 1990: 794; 2000: 1,250 } \\
\hline Years Since Migration (YSM) & $\begin{array}{c}-0.010 \\
(0.33)\end{array}$ & $\begin{array}{c}-0.003 \\
(0.52)\end{array}$ & $\begin{array}{c}-0.004 \\
(0.46)\end{array}$ & $\begin{array}{r}-0.002 \\
(0.45)\end{array}$ & $\begin{array}{c}-0.015 \\
(2.30)\end{array}$ & $\begin{array}{c}-0.004 \\
(1.64)\end{array}$ \\
\hline $\mathrm{YSM}^{2} / 100$ & $\begin{array}{c}0.018 \\
(0.25)\end{array}$ & $*$ & $\begin{array}{c}-0.006 \\
(0.32)\end{array}$ & $*$ & $\begin{array}{c}0.025 \\
(1.71)\end{array}$ & $*$ \\
\hline
\end{tabular}

a Full set of results available upon request by emailing the authors.

b Absolute value of heteroskedasticity-consistent t-statistics in parentheses.

${ }^{c}$ Asterisk indicates variable not entered.

Notes: The estimating equation also holds constant educational attainment, labor market experience and its square, $\log$ of weeks worked, whether currently married (spouse present), whether the respondent lives in the South or a rural $(1980,1990)$ or non-metropolitan (2000) area, proficiency in English if a language other than English is spoken at home, and country of origin dichotomous variables (U.K. as benchmark).

Sources: U.S. Censuses of Population: 1980 1\% PUMS; 1990 5\% PUMS; 2000 5\% PUMS.

The coefficients imply $5.5 \%$ lower earnings for those who migrated to Australia from the ESDC in 1988 compared to those who immigrated in 1998. This compares with a decline of $7 \%$ over a ten-year period for ESDC immigrants in the U.S. 2000 Census (Table 3, last column).

\section{Sweden}

Migration among the five Nordic countries might offer another test of the negative assimilation hypothesis. Four Nordic countries-Sweden, Denmark, Norway, and
Iceland-are of roughly similar levels of income and the languages are quite similar. Most of the ethnic Swedish and ethnic Finnish migrants from Finland to Sweden know Swedish. ${ }^{18}$ Many of the cultural characteristics and institutions are similar across these five countries. Notably, there is unrestricted labor mobility across the Nordic countries.

\footnotetext{
${ }^{18}$ The Finnish language is of central Asian origin, as is Hungarian, and is quite different from the other Scandinavian languages.
} 
Table 7. Partial Effect of Duration of Residence on the Earnings of Adult Male Immigrants from the ESDC, 2001 Australian Census

\begin{tabular}{lcc}
\hline Period of Immigration & ESDC & Other Countries \\
\hline $1991-1995$ & -0.040 & 0.011 \\
& $(0.92)$ & $(0.32)$ \\
$1986-1990$ & -0.055 & 0.031 \\
& $(1.58)$ & $(0.85)$ \\
Before 1986 & -0.085 & 0.107 \\
& $(3.31)$ & $(3.65)$ \\
\hline
\end{tabular}

Notes: The sample size is 3,127 , the benchmark immigration category is "Immigrated after 1995," and t-ratios are in parentheses. The estimating equation includes variables for schooling, labor market experience, marital status, and log weeks worked. Source: Chiswick and Miller (2008b), Table 1, S48.

Pedersen et al. (2008) studied the 2005 wages of immigrants in Sweden from both the ten Eastern European countries that joined the European Union in May 2004 and the four other Nordic countries. ${ }^{19}$ According to them, immigrants in Sweden from the EU-10

have lower wages than the natives and those who have arrived recently have lower wages than those coming earlier, controlling for age, education, and gender. For those coming from the Nordic countries the pattern is quite different. The wage differential is much smaller and those who have arrived earlier have a wage disadvantage compared to those who arrived in more recent periods. (pp. 105-6, Table 5.8)

Indeed, recent immigrants from each of the four Nordic countries have higher earnings than those born in Sweden, other variables the same, with the earnings advantage declining with duration and eventually becoming negative. This pattern is consistent with the negative assimilation hypothesis.

\section{Immigrant Versus Native Earnings Over Time}

Tables 8 and 9 list the coefficients of the duration of residence variables from the regression equations estimated on pooled samples of the native- and foreign-born in the United States for each Census year.

19 The results from Pedersen et al. (2008) discussed here are reproduced in Appendix B, which is available from the authors on request.
Table 8 contains results for 1990 and 2000 and Table 9 contains results for 1980, 1990, and 2000. The analyses differ by the level of detail on the duration of residence variables to the extent permitted by the Census with the least amount of information in the set of comparisons conducted (the 1990 Census period of arrival categories when only 2000 and 1990 data are compared, and the 1980 Census categories for period of arrival when 1980, 1990 and 2000 data are comparedsee Table 1 for details).

For the native-born, a 25\% subset of the $1 \%$ PUMS for each Census was used in these analyses, a sampling procedure that yielded more than 100,000 observations for this group, which is more than adequate for the comparisons conducted. Column (i) of Table 8 reports the mean difference in earnings among adult men between the immigrants from the ESDC and the U.S. native-born. The regression equations in Table 8 contain the set of standardizing variables used in Table 3 and a set of birthplace variables (for immigrants from the United Kingdom, Ireland, Canada, and Australia/ New Zealand, respectively). One set of the estimates (Table 8, column (ii)) comes from equations that constrain the estimates of each of the human capital and demographic variables from Table 3 to be the same for the native- and the foreign-born. The second set includes a full set of interaction terms between these variables and birthplace (Table 8, column (iii)). The inclusion of these interaction terms has minimal impact 
Table 8. Coefficients on Birthplace and Duration of Residence Variables from Analysis on Pooled Sample of Native-born and Foreign-Born Workers, 1990 and 2000 U.S. Censuses ${ }^{\mathrm{a}}$

\begin{tabular}{|c|c|c|c|c|c|c|}
\hline \multirow[b]{2}{*}{ Variable $^{\mathrm{c}}$} & \multicolumn{3}{|c|}{1990} & \multicolumn{3}{|c|}{2000} \\
\hline & $\begin{array}{c}\text { Difference } \\
\text { in Mean } \\
\text { Earnings }^{\mathrm{b}} \\
\quad(i)\end{array}$ & $\begin{array}{c}\text { Without } \\
\text { Birthplace } \\
\text { Interactions } \\
\text { (ii) }\end{array}$ & $\begin{array}{c}\text { With } \\
\text { Birthplace } \\
\text { Interactions } \\
\text { (iii) }\end{array}$ & $\begin{array}{c}\text { Difference } \\
\text { in Mean } \\
\text { Earnings }^{\mathrm{b}} \\
\quad(i)\end{array}$ & $\begin{array}{c}\text { Without } \\
\text { Birthplace } \\
\text { Interactions } \\
\text { (ii) }\end{array}$ & $\begin{array}{c}\text { With } \\
\text { Birthplace } \\
\text { Interactions } \\
\text { (iii) }\end{array}$ \\
\hline \multicolumn{7}{|c|}{ Birthplace (native-born as benchmark) } \\
\hline U.K. & $\begin{array}{c}0.360 \\
(30.45)\end{array}$ & $\begin{array}{c}0.149 \\
(8.16)\end{array}$ & $\begin{array}{c}0.216 \\
(1.66)\end{array}$ & $\begin{array}{c}0.399 \\
(36.67)\end{array}$ & $\begin{array}{c}0.315 \\
(21.17)\end{array}$ & $\begin{array}{c}0.299 \\
(2.27)\end{array}$ \\
\hline Ireland & $\begin{array}{r}0.261 \\
(13.08)\end{array}$ & $\begin{array}{c}0.182 \\
(8.05)\end{array}$ & $\begin{array}{c}0.225 \\
(1.74)\end{array}$ & $\begin{array}{c}0.223 \\
(11.14)\end{array}$ & $\begin{array}{r}0.319 \\
(14.82)\end{array}$ & $\begin{array}{c}0.302 \\
(2.28)\end{array}$ \\
\hline Canada & $\begin{array}{r}0.247 \\
(20.66)\end{array}$ & $\begin{array}{c}0.145 \\
(7.50)\end{array}$ & $\begin{array}{c}0.206 \\
(1.58)\end{array}$ & $\begin{array}{c}0.322 \\
(30.33)\end{array}$ & $\begin{array}{c}0.303 \\
(21.02)\end{array}$ & $\begin{array}{c}0.289 \\
(2.20)\end{array}$ \\
\hline Australia \& N.Z. & $\begin{array}{r}0.248 \\
(5.56)\end{array}$ & $\begin{array}{r}0.081 \\
(1.94)\end{array}$ & $\begin{array}{c}0.156 \\
(1.12)\end{array}$ & $\begin{array}{r}0.392 \\
(13.10)\end{array}$ & $\begin{array}{c}0.304 \\
(11.19)\end{array}$ & $\begin{array}{c}0.290 \\
(2.19)\end{array}$ \\
\hline \multicolumn{7}{|c|}{ Duration of Residence (0-4 years as benchmark) } \\
\hline $5-9$ yrs & $*$ & $\begin{array}{c}0.071 \\
(2.88)\end{array}$ & $\begin{array}{c}0.051 \\
(2.09)\end{array}$ & * & $\begin{array}{c}-0.046 \\
(2.31)\end{array}$ & $\begin{array}{c}-0.056 \\
(2.82)\end{array}$ \\
\hline $10-14$ yrs & $*$ & $\begin{array}{c}0.060 \\
(2.11)\end{array}$ & $\begin{array}{r}0.030 \\
(1.04)\end{array}$ & $*$ & $\begin{array}{r}-0.101 \\
(4.78)\end{array}$ & $\begin{array}{c}-0.126 \\
(5.88)\end{array}$ \\
\hline $15-19$ yrs & $*$ & $\begin{array}{c}0.024 \\
(0.84)\end{array}$ & $\begin{array}{c}-0.010 \\
(0.36)\end{array}$ & $*$ & $\begin{array}{c}-0.085 \\
(3.81)\end{array}$ & $\begin{array}{c}-0.118 \\
(5.27)\end{array}$ \\
\hline $20-24$ yrs & $*$ & $\begin{array}{c}0.035 \\
(1.52)\end{array}$ & $\begin{array}{c}-0.005 \\
(0.22)\end{array}$ & $*$ & $\begin{array}{r}-0.117 \\
(4.99)\end{array}$ & $\begin{array}{c}-0.151 \\
(6.40)\end{array}$ \\
\hline $25-29$ yrs & $*$ & $\begin{array}{c}0.007 \\
(0.32)\end{array}$ & $\begin{array}{c}-0.042 \\
(1.75)\end{array}$ & $*$ & $\begin{array}{c}-0.125 \\
(4.91)\end{array}$ & $\begin{array}{c}-0.164 \\
(6.32)\end{array}$ \\
\hline $30-39$ yrs & $*$ & $\begin{array}{c}-0.033 \\
(1.49)\end{array}$ & $\begin{array}{c}-0.088 \\
(3.66)\end{array}$ & $*$ & $\begin{array}{c}-0.155 \\
(8.20)\end{array}$ & $\begin{array}{l}-0.211 \\
(10.35)\end{array}$ \\
\hline $40+\mathrm{yrs}$ & $*$ & $\begin{array}{c}-0.079 \\
(2.57)\end{array}$ & $\begin{array}{c}-0.145 \\
(4.34)\end{array}$ & $*$ & $\begin{array}{c}-0.232 \\
(10.73)\end{array}$ & $\begin{array}{c}-0.303 \\
(12.62)\end{array}$ \\
\hline $\mathrm{R}^{2}$ & 0.0100 & 0.3749 & 0.3754 & 0.0158 & 0.3316 & 0.3319 \\
\hline Sample Size & 140,344 & 140,344 & 140,344 & 155,254 & 155,254 & 155,254 \\
\hline
\end{tabular}

${ }^{a}$ Full set of results available upon request by emailing the authors. Absolute value of heteroskedasticity-consistent t-statistics in parentheses.

${ }^{\mathrm{b}}$ Difference in mean log earnings from the native-born.

${ }^{c}$ Asterisk indicates variable not entered.

Notes: The estimating equation also holds constant educational attainment, labor market experience and its square, $\log$ of weeks worked, whether currently married (spouse present), whether the respondent lives in the South or a rural $(1980,1990)$ or non-metropolitan (2000) area, proficiency in English if a language other than English is spoken at home, and country of origin dichotomous variables, with the native-born as the country benchmark.

Sources: U.S. Censuses of Population: 1980 1\% PUMS; 1990 5\% PUMS; 2000 5\% PUMS.

on the comparisons that can be made across the duration of residence categories. It has, however, a marked impact in some analyses on the magnitude of the native bornimmigrant comparisons, ceteris paribus, a result consistent with previous findings (e.g., see Funkhouser and Trejo 1995).
Table 8 has four main features. First, according to the figures in column (i), the mean earnings of immigrants from the United Kingdom, Canada, and Australia/ New Zealand, relative to the native-born, increased between 1990 and 2000. The mean earnings of immigrants from Ireland, 
Table 9. Coefficients on Birthplace and Duration of Residence Variables from Analysis on Pooled Sample of Native-born and Foreign-Born Workers, 1980, 1990 and 2000 U.S. Censuses ${ }^{\mathrm{a}, \mathrm{b}}$

\begin{tabular}{|c|c|c|c|c|c|c|}
\hline \multirow[b]{2}{*}{ Variable } & \multicolumn{2}{|c|}{$1980^{\circ}$} & \multicolumn{2}{|c|}{1990} & \multicolumn{2}{|c|}{2000} \\
\hline & $\begin{array}{c}\text { Without } \\
\text { Birthplace } \\
\text { Interactions }\end{array}$ & $\begin{array}{c}\text { With } \\
\text { Birthplace } \\
\text { Interactions }\end{array}$ & $\begin{array}{c}\text { Without } \\
\text { Birthplace } \\
\text { Interactions }\end{array}$ & $\begin{array}{c}\text { With } \\
\text { Birthplace } \\
\text { Interactions }\end{array}$ & $\begin{array}{c}\text { Without } \\
\text { Birthplace } \\
\text { Interactions }\end{array}$ & $\begin{array}{c}\text { With } \\
\text { Birthplace } \\
\text { Interactions }\end{array}$ \\
\hline \multicolumn{7}{|c|}{ Birthplace (native-born as benchmark) } \\
\hline U.K. & $\begin{array}{c}0.048 \\
(1.13)\end{array}$ & $\begin{array}{r}-0.337 \\
(1.24)\end{array}$ & $\begin{array}{c}0.149 \\
(8.19)\end{array}$ & $\begin{array}{c}0.218 \\
(1.68)\end{array}$ & $\begin{array}{c}0.315 \\
(21.19)\end{array}$ & $\begin{array}{r}0.307 \\
(2.33)\end{array}$ \\
\hline Ireland & $\begin{array}{c}-0.018 \\
(0.31)\end{array}$ & $\begin{array}{c}-0.424 \\
(1.54)\end{array}$ & $\begin{array}{c}0.183 \\
(8.07)\end{array}$ & $\begin{array}{c}0.228 \\
(1.76)\end{array}$ & $\begin{array}{c}0.318 \\
(14.78)\end{array}$ & $\begin{array}{c}0.308 \\
(2.32)\end{array}$ \\
\hline Canada & $\begin{array}{c}0.063 \\
(1.33)\end{array}$ & $\begin{array}{c}-0.321 \\
(1.18)\end{array}$ & $\begin{array}{c}0.144 \\
(7.44)\end{array}$ & $\begin{array}{c}0.206 \\
(1.58)\end{array}$ & $\begin{array}{r}0.302 \\
(20.97)\end{array}$ & $\begin{array}{c}0.295 \\
(2.24)\end{array}$ \\
\hline Australia \& N.Z. & $\begin{array}{c}-0.038 \\
(0.47)\end{array}$ & $\begin{array}{c}-0.410 \\
(1.46)\end{array}$ & $\begin{array}{r}0.082 \\
(1.95)\end{array}$ & $\begin{array}{c}0.158 \\
(1.13)\end{array}$ & $\begin{array}{r}0.305 \\
(11.20)\end{array}$ & $\begin{array}{c}0.298 \\
(2.24)\end{array}$ \\
\hline \multicolumn{7}{|c|}{ Duration of Residence (0-4 years as benchmark) } \\
\hline $5-9$ yrs & $\begin{array}{c}0.109 \\
(1.65)\end{array}$ & $\begin{array}{c}0.079 \\
(1.18)\end{array}$ & $\begin{array}{c}0.071 \\
(2.89)\end{array}$ & $\begin{array}{c}0.052 \\
(2.11)\end{array}$ & $\begin{array}{c}-0.046 \\
(2.30)\end{array}$ & $\begin{array}{c}-0.056 \\
(2.78)\end{array}$ \\
\hline $10-14$ yrs & $\begin{array}{c}0.127 \\
(2.24)\end{array}$ & $\begin{array}{c}0.076 \\
(1.29)\end{array}$ & $\begin{array}{c}0.060 \\
(2.12)\end{array}$ & $\begin{array}{r}0.031 \\
(1.07)\end{array}$ & $\begin{array}{c}-0.101 \\
(4.77)\end{array}$ & $\begin{array}{c}-0.125 \\
(5.82)\end{array}$ \\
\hline $15-19$ yrs & $\begin{array}{c}0.056 \\
(1.03)\end{array}$ & $\begin{array}{c}-0.002 \\
(0.04)\end{array}$ & $\begin{array}{c}0.024 \\
(0.85)\end{array}$ & $\begin{array}{c}-0.009 \\
(0.32)\end{array}$ & $\begin{array}{c}-0.085 \\
(3.81)\end{array}$ & $\begin{array}{c}-0.116 \\
(5.17)\end{array}$ \\
\hline $20-29$ yrs & $\begin{array}{c}0.050 \\
(1.03)\end{array}$ & $\begin{array}{c}-0.002 \\
(0.04)\end{array}$ & $\begin{array}{c}0.020 \\
(1.00)\end{array}$ & $\begin{array}{c}-0.023 \\
(1.09)\end{array}$ & $\begin{array}{c}-0.120 \\
(6.19)\end{array}$ & $\begin{array}{c}-0.154 \\
(7.78)\end{array}$ \\
\hline $30+\mathrm{yrs}$ & $\begin{array}{r}-0.007 \\
(0.14)\end{array}$ & $\begin{array}{c}-0.069 \\
(1.19)\end{array}$ & $\begin{array}{c}-0.045 \\
(2.12)\end{array}$ & $\begin{array}{c}-0.100 \\
(4.25)\end{array}$ & $\begin{array}{l}-0.185 \\
(10.98)\end{array}$ & $\begin{array}{l}-0.242 \\
(12.81)\end{array}$ \\
\hline $\mathrm{R}^{2}$ & 0.3221 & 0.3222 & 0.3748 & 0.3754 & 0.3315 & 0.3318 \\
\hline Sample Size & 107,402 & 107,402 & 140,344 & 140,344 & 155,254 & 155,254 \\
\hline
\end{tabular}

${ }^{a}$ Full set of results available upon request by emailing the authors.

${ }^{\mathrm{b}}$ Absolute value of heteroskedasticity-consistent t-statistics in parentheses.

c The mean earnings advantage in 1980 for the foreign-born compared to the native-born is 0.258 for immigrants from the U.K., 0.139 for immigrants from Ireland, 0.162 for immigrants from Canada, and 0.126 for immigrants from Australia/New Zealand.

Notes: The estimating equation also holds constant educational attainment, labor market experience and its square, $\log$ of weeks worked, whether currently married (spouse present), whether the respondent lives in the South or a rural $(1980,1990)$ or non-metropolitan (2000) area, proficiency in English if a language other than English is spoken at home, and country of origin dichotomous variables, with the native-born as the country benchmark.

Sources: U.S. Censuses of Population: 1990 5\% PUMS; 2000 5\% PUMS.

however, fell by four percentage points relative to the mean earnings of the native-born over this period. Second, in the 1990 Census data, regardless of the specification of the estimating equation (column (ii) or column (iii)), there is evidence of positive adjustment over the first decade in the United States (earnings were higher for those in the United States five to nine years than those in the United States zero to four years). Beyond this point, however, the estimates are consistent with the negative assimilation hypothesis; earnings decline with a longer duration. Third, the 2000 data exhibit a pattern consistent with the negative assimilation hypothesis across all duration intervals. As Figure 1 illustrates, beyond five years of residence, the profiles of the immigrant-native-born earnings differentials by duration of residence for 2000 and 1990, for all intents and 
Figure 1. Earnings for Foreign-Born Relative to Native-Born Adult Men by Duration of Residence Category, Ceteris Paribus, 1990 and 2000 U.S. Censuses

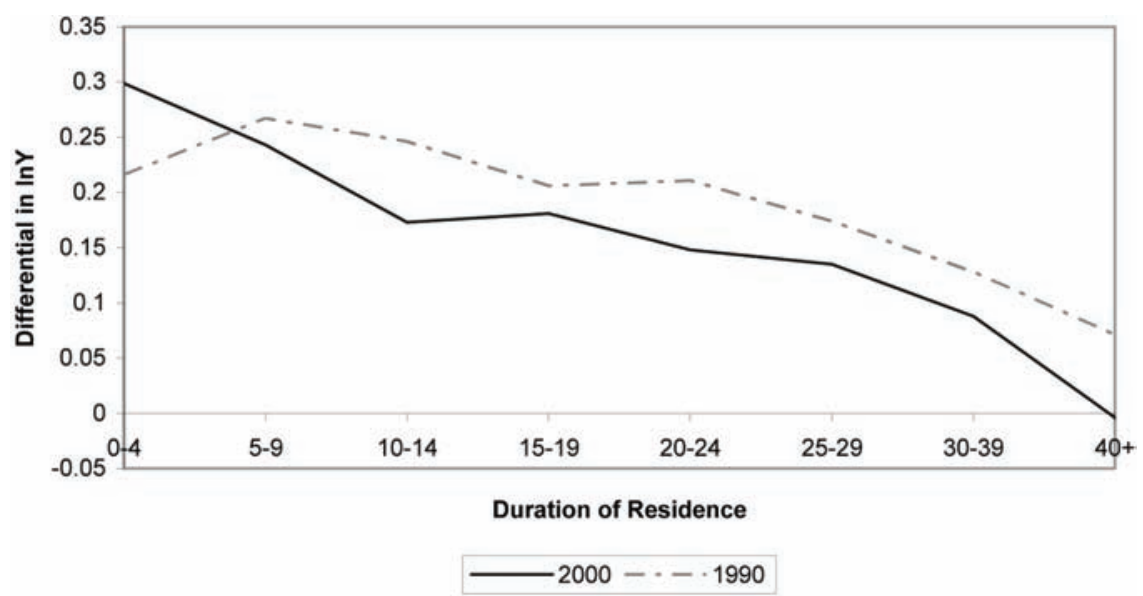

Source: Authors' calculations from Table 8, column (iii).

purposes, have a negative slope and are parallel.

In compiling Figure 1, we have used the duration-of-residence coefficients from the model with birthplace interaction terms. The intercept points are given by the coefficients on the dummy variable for immigrants from the United Kingdom. This brings us to the fourth feature of the results in Table 8: the intercept point (or the earnings advantage that immigrants have over the native-born, ceteris paribus) for 2000 is higher than for 1990. This is generally taken as evidence for an increase over time in the unobservable qualities of immigrants relative to the native-born. At each of the other durations of residence, however, the earnings profile for the foreign-born for 1990 is above that for 2000 . In other words, when looking at the data for 1990 and 2000, the evidence on the unobservable change in the qualities of immigrant cohorts is ambiguous.

Table 9 presents parallel information for the analyses of the 1980, 1990, and 2000 Censuses. The pattern of earnings effects with duration of residence for 1980 is a diluted version of that which characterized the data a decade later, in 1990. The immigrant earnings advantage over the native-born in 1990 and 2000 is considerably greater than in 1980, suggesting that the 1980s and 1990s were characterized by different selection among immigrants from English-speaking developed countries than in earlier years. The large negative coefficients on the birthplace variables for 1980 in the specification with birthplace interaction effects are due mainly to different earnings effects of the weeks-worked variable: the coefficient on this for the foreign-born was 1.149, and that for the native-born 1.062. In comparison, in 2000 the coefficient on the weeks-worked variable was 0.975 for the foreign-born and 1.024 for the native-born.

The relatively flat earnings duration-ofresidence profile in 1980 and the steeper negative profile in 1990 and 2000, together with the increases in the positive immigrantnative-born earnings differential over time, ceteris paribus, suggest there may be merit to the estimation of a cohort model. In this application, our approach follows Funkhouser and Trejo (1995).

The cohort model may be written as:

$$
\begin{aligned}
\text { In } Y_{i}= & \alpha+X_{i} \beta+Y S M_{i} \gamma_{1}+Y S M S Q_{i} \gamma_{2} \\
& +C_{i} \delta+T_{i} \phi+\varepsilon_{i},
\end{aligned}
$$


where income $(Y)$ is the annual earnings from wage and salaried employment and self-employment; $X_{i}$ is the set of human capital and demographic standardizing variables used above; $Y S M_{i}$ is the number of years an immigrant has spent in the United States; $C_{i}$ is a vector of dummy variables indicating the immigrant cohort of arrival; $T_{i}$ is a vector of dummy variables for the Census year; and $\varepsilon_{i}$ is a stochastic disturbance term. In this earnings equation, $\gamma_{1}$ and $\gamma_{2}$ capture the pattern of immigrant assimilation, and $\delta$ captures cohort differences in the intercept of the earnings profile. This specification constrains the coefficients on the $X_{i}$ variables to be the same across birthplace groups and across time periods, and these restrictions are inconsistent with the evidence in Table 3 (for changes over time) and Table 8 (statistically significant birthplace interactions). Funkhouser and Trejo (1995: 804) noted that this constraint is not necessary, and they presented estimates from a more general specification that allows the effects of their human capital variables to vary with nativity. Borjas (1995) also favored a more general model that allows for interactions of the $X_{i}$ variables with immigrant status and the period effects. We have adopted a general specification that allows the coefficients of the $X_{i}$ variables to change over time as well as to differ between the native-born and foreignborn..$^{20}$

We estimated two models: the first is based on a pooling of the data for 1990 and 2000, and the second is based on a pooling of the data for 1980, 1990, and 2000. McDonald and Worswick (1998) have shown that the estimates of (positive) assimilation and cohort differences using a small number of crosssectional surveys are sensitive to the choice of survey years. In this regard, the weak negative assimilation effect found using the

\footnotetext{
20 The findings based on only the 1990 and 2000 data are reasonably robust to imposing restrictions on these coefficients across time and between birthplaces. The results following the addition of the 1980 data are, however, sensitive to most restrictions imposed. Thus, we present only the findings from the more complex specification.
}

1980 Census data (see Table 3) and the small number of immigrant cohorts (six) distinguished in that data set suggest, a priori, that the findings from analyses that also cover 1980 will be weaker than when the 1980 data are not used. We have estimated both a general specification of immigrant assimilation based on a quadratic in years since migration and a model with years since migration in linear form. Notably, we have not imposed sample inclusions, which are sometimes used to mimic a synthetic cohort (e.g., restrict the analysis to 25 to 44 -yearolds in 1980, 35 to 54-year-olds in 1990 and 45 to 64-year-olds in 2000), in this analysis. The sample used is simply a pooled version of the samples used in the separated analyses of the 1980, 1990, and 2000 data above. Table 10 lists the relevant information from this cohort approach.

The results in Table 10 present consistent evidence that immigrants in the 1995-2000 cohort have higher earnings relative to the native-born than the earlier arrival cohorts, although the advantage is not great. From the analysis based only on the 1990 and 2000 Census data, the variations in earnings by arrival cohort are modest: the smallest earnings effects relative to the native-born are associated with the 1950-59 arrival cohort. ${ }^{21}$ All other arrival cohorts are associated with positive earnings effects compared to the native-born of between 0.21 and 0.37 . The analysis based on the 1980, 1990, and 2000 Census data also indicates that the earlier arrival cohorts have a smaller earnings advantage over the native-born than the more recent arrival cohorts. In other words, the unmeasured dimensions of immigrant quality have increased over time compared to the native-born.

In the models in which years since migration is entered as a quadratic, the squared term is statistically significant whereas the linear term is not. In the simpler specification with only a linear years-since-migration variable, this is negative and statistically significant in the analyses based on the 1990

\footnotetext{
${ }^{21}$ Funkhouser and Trejo (1995) also reported that the pre-1960 cohort fares the worst in their analysis.
} 
Table 10. Estimates of Cohort Model for the United States, 1980, 1990 and 2000 U.S. Censuses ${ }^{\mathrm{a}, \mathrm{b}}$

\begin{tabular}{|c|c|c|c|c|}
\hline \multirow{3}{*}{$\frac{\text { Arrival Cohort }}{1995-2000}$} & \multicolumn{4}{|c|}{ Data Sets } \\
\hline & \multicolumn{2}{|c|}{$1990+2000$} & \multicolumn{2}{|c|}{$1980+1990+2000$} \\
\hline & 0.370 & 0.379 & 0.197 & 0.217 \\
\hline & (4.12) & $(4.22)$ & $(2.49)$ & $(2.75)$ \\
\hline \multirow[t]{2}{*}{$1990-1994$} & 0.303 & 0.333 & 0.142 & 0.177 \\
\hline & $(3.32)$ & $(3.66)$ & (1.83) & $(2.29)$ \\
\hline \multirow{2}{*}{$1985-1989$} & 0.223 & 0.248 & 0.079 & 0.102 \\
\hline & $(2.47)$ & $(2.76)$ & (1.03) & $(1.34)$ \\
\hline \multirow{2}{*}{$1980-1984$} & 0.255 & 0.298 & 0.115 & 0.148 \\
\hline & $(2.79)$ & $(3.29)$ & (1.44) & $(1.85)$ \\
\hline \multirow[t]{2}{*}{$1975-1979$} & 0.232 & 0.283 & 0.085 & 0.099 \\
\hline & $(2.50)$ & $(3.10)$ & (1.01) & $(1.17)$ \\
\hline \multirow[t]{2}{*}{$1970-1974$} & 0.218 & 0.272 & 0.115 & 0.130 \\
\hline & $(2.31)$ & $(2.93)$ & (1.24) & $(1.40)$ \\
\hline \multirow[t]{2}{*}{$1965-1969$} & 0.227 & 0.278 & 0.135 & 0.142 \\
\hline & $(2.41)$ & $(2.99)$ & (1.32) & (1.39) \\
\hline \multirow[t]{2}{*}{$1960-1964$} & 0.206 & 0.250 & 0.111 & 0.103 \\
\hline & $(2.16)$ & $(2.65)$ & $(0.98)$ & $(0.91)$ \\
\hline \multirow[t]{2}{*}{$1950-1959$} & 0.191 & 0.215 & 0.132 & 0.096 \\
\hline & (1.97) & $(2.23)$ & (1.01) & $(0.74)$ \\
\hline \multirow[t]{2}{*}{ Before 1950} & 0.248 & 0.211 & 0.214 & 0.097 \\
\hline & $(2.37)$ & $(2.04)$ & $(1.26)$ & $(0.58)$ \\
\hline \multirow{2}{*}{$\begin{array}{l}\text { Years Since Migration } \\
\text { (YSM) }\end{array}$} & 0.003 & -0.003 & 0.001 & -0.003 \\
\hline & (1.18) & (2.72) & $(0.23)$ & $(1.13)$ \\
\hline \multirow[t]{2}{*}{$\mathrm{YSM}^{2} / 100$} & -0.012 & $*$ & -0.014 & $*$ \\
\hline & (2.87) & & $(4.71)$ & \\
\hline $\mathrm{R}^{2}$ & 0.3742 & 0.3742 & 0.4178 & 0.4177 \\
\hline Sample Size & 295,598 & 295,598 & 403,000 & 403,000 \\
\hline
\end{tabular}

a Full set of results available upon request by emailing the authors.

b Absolute value of heteroskedasticity-consistent t-statistics in parentheses.

c Asterisk indicates variable not entered.

Notes: The estimating equation also holds constant educational attainment, labor market experience and its square, $\log$ of weeks worked, whether currently married (spouse present), whether the respondent lives in the South or a rural $(1980,1990)$ or non-metropolitan (2000) area, proficiency in English if a language other than English is spoken at home, and country of origin dichotomous variables, with the native-born as the country benchmark.

Sources: U.S. Censuses of Population: 1980 1\% PUMS; 1990 5\% PUMS; 2000 5\% PUMS.

and 2000 data, and negative but statistically insignificant when the 1980 data are also used. The estimated coefficient is -0.003 in each instance. This compares with values of between -0.003 to -0.007 in the cross-sectional analyses reported above. In other words, adjustment for differences in the quality of immigrant cohorts, in a situation in which there is an apparent increase in unobserved dimensions of immigrant quality over time, results in a weaker assimilation effect. And yet, the negative assimilation effect remains in the data, particularly when the more recent Censuses that appear to be characterized by more pronounced negative assimilation (see Table 3 ) are analyzed..$^{22}$

\footnotetext{
${ }^{22}$ We performed a test for the cohort analysis in which the data were separated into adult and child immigrants. The findings for adult and child immigrants reported above persist when cohort analysis is performed.
} 


\section{Summary and Conclusion}

The international migration literature has been dominated to date by empirical testing of the immigrant assimilation hypothesis. The main testable implication of this hypothesis is that immigrant earningsand other labor market and economic outcomes-will improve with duration of residence in the destination country. Evidence consistent with this hypothesis has been found for all the major immigrantreceiving countries, time periods, and data sets that have been examined.

In this paper, we have addressed whether such positive assimilation occurs if skills are highly transferable internationally. We hypothesized that in cases in which countries are of approximately equal economic standing and immigrants' skills are highly transferable, international migration among these countries will typically occur when the individual experiences a favorable draw from the distribution of wage offers in the potential destination relative to the wage available in the country of origin and there will be little or no post-migration investment in destination-specific human capital. A relatively high wage offer that attracts the immigrant, particularly if it is a high random wage, need not persist indefinitely. With the passage of time, a "regression to the mean" would be expected, which will be reflected empirically by a negative relationship between earnings and duration of residence in the destination. This "negative" assimilation is not due to a deterioration of skills (quantity of human capital) but due to a relative decline in the wage rate (price).

Our analysis of the earnings of adult, foreign-born men from the English-Speaking Developed Countries (ESDC) in the 1980, 1990, and 2000 U.S. Censuses reveals strong support for the negative assimilation hypothesis. It also indicates that this "negative" assimilation has strengthened over time. An examination of immigrant earnings relative to the earnings of the native-born, using both a standard cross-section approach and a cohort model, also showed strong support for the negative assimilation hypothesis. Note that the negative assimilation found among immigrants to the United States born in the other English-Speaking Developed Countries occurs in the same Census data in which positive assimilation (earnings increasing with duration) is found for immigrants born in other countries.

Statistical testing rejects the hypothesis that the negative assimilation effect is due to a rise over time in the cohort quality of the ESDC immigrants. For the findings for immigrants from the ESDC (negative assimilation) and for immigrants from other countries (positive assimilation) to be consistent with selective return migration, the return migrants would need to be favorably selected among the former but adversely selected among the latter immigrants. This differential selectivity seems implausible.

The reporting of analyses for immigrants from the other ESDC for Australia (2001 Census) and for Nordic immigrants in Sweden also reveals a relative decline in earnings with duration of residence, whereas the earnings of other immigrants in these countries increase with duration. This is consistent with the negative assimilation hypothesis developed in this paper.

Whether immigrant earnings assimilation is positive or negative depends on the degree of the international transferability of skills, the extent of post-migration investment in human capital, and the rate of return on this investment.

Negative, rather than positive, assimilation is the pattern that characterizes the earningsduration of residence relationship among immigrants from the English-speaking developed countries in the United States, Australia, and among Nordic immigrants in Sweden. As with Chiswick's $(1978,1979)$ model of three decades ago, we hope future research for other countries, data sets, and time periods will test whether this is a universal finding for immigrants from countries of similar economic standing and very high skill transferability to that of the destination country. 


\section{Appendix A}

\section{Description of Variables for Analysis for the United States}

Data Source: 2000 Census of Population of the United States, Public Use Microdata Sample (PUMS), 5\% sample; 1990 Census PUMS 5\% sample; and 1980 Census $1 \%$ sample.

Definition of Population: Foreign-born and nativeborn men aged 25 to 64 . The foreign-born are limited to those born in Canada, the United Kingdom (and its constituent units), Ireland, Australia and New Zealand. Only residents of the 50 States and the District of Columbia are considered.

\section{Dependent variable}

Earnings (LNEARN): The natural logarithm of earnings in the year prior to the census year for those reporting that they worked in that year. Earnings are the sum of wage and salary and self-employment earnings. Values less than 100 , including zero and negative values, are assigned the value 100 .

\section{Independent variables}

Years of Education (EDUC): This variable records the total years of full-time equivalent education. This has been constructed from the Census data on educational attainment by assigning the following values to the Census categories: completed less than fifth grade (2 years); completed fifth or sixth grade (5.5); completed seventh or eighth grade (7.5); completed ninth grade (9); completed tenth grade (10); completed eleventh grade (11); completed twelfth grade or high school (12); attended college for less than one year (12.5); attended college for more than one year or completed college (14); Bachelor's degree (16); master's degree (17.5); professional degree (18.5); doctorate (20).

Potential Experience: This is the individual's age minus years of education minus six.
Years Since Migration (YSM). This is computed from the year the foreign-born person came to the United States to stay. For the 1980 and 1990 Censuses, the midpoint of the period of arrival intervals are used.

Log of Weeks Worked: This is the natural logarithm of the number of weeks the person worked in the year prior to the census year (e.g., 1999 for the 2000 Census, and so on).

Marital Status (MARRIED): This is a dichotomous variable that distinguishes individuals who are married, spouse present (equal to 1) from all other marital states.

English Proficiency: Two dichotomous variables are used to summarize the individual's proficiency in spoken English. The first is for those who speak a language other than English at home and speak English very well or well. The second is for those who speak a language other than English at home and speak English not well or not at all. The reference group is those who speak only English at home.

Country of Origin: Separate dichotomous variables for persons born in Canada, the United Kingdom (U.K.) (and its constituent units), Ireland, and Australia/New Zealand. French Canadians are distinguished from Other Canadians by whether they report speaking French at home. Because of sample sizes and the similarities of their origins, Australians and New Zealanders are combined.

Location: The size-of-place location variables record residence in a rural area (1980 and 1990 Census) and a non-metropolitan area (2000 Census). The Southern States (SOUTH) are: Alabama, Arkansas, Delaware, District of Columbia, Florida, Georgia, Kentucky, Louisiana, Maryland, Mississippi, Missouri, North Carolina, Oklahoma, South Carolina, Tennessee, Texas, Virginia, West Virginia. 
Appendix Table A1

Means and Standard Deviations of Variables in Immigrant Earnings Function, 25 to 64-Year-Old Male Immigrants from English-Speaking Developed Countries, 1980, 1990 and 2000 U.S. Censuses

\begin{tabular}{|c|c|c|c|}
\hline Variable & 1980 & 1990 & 2000 \\
\hline Log Earnings & $\begin{array}{c}9.731 \\
(0.97)\end{array}$ & $\begin{array}{l}10.313 \\
(1.03)\end{array}$ & $\begin{array}{l}10.725 \\
(1.02)\end{array}$ \\
\hline Educational Attainment & $\begin{array}{l}13.644 \\
(3.60)\end{array}$ & $\begin{array}{c}14.276 \\
(2.94)\end{array}$ & $\begin{array}{l}14.866 \\
(2.70)\end{array}$ \\
\hline Experience (EXP) & $\begin{array}{c}25.785 \\
(12.83)\end{array}$ & $\begin{array}{r}22.327 \\
(11.69)\end{array}$ & $\begin{array}{r}23.115 \\
(10.88)\end{array}$ \\
\hline Years Since Migration (YSM) & $\begin{array}{c}22.049 \\
(12.63)\end{array}$ & $\begin{array}{c}21.575 \\
(13.87)\end{array}$ & $\begin{array}{c}20.480 \\
(14.71)\end{array}$ \\
\hline Log Weeks Worked & $\begin{array}{c}3.827 \\
(0.38)\end{array}$ & $\begin{array}{c}3.818 \\
(0.40)\end{array}$ & $\begin{array}{r}3.825 \\
(0.39)\end{array}$ \\
\hline Married & $\begin{array}{c}0.809 \\
(0.39)\end{array}$ & $\begin{array}{c}0.711 \\
(0.45)\end{array}$ & $\begin{array}{r}0.677 \\
(0.47)\end{array}$ \\
\hline South & $\begin{array}{c}0.162 \\
(0.37)\end{array}$ & $\begin{array}{c}0.217 \\
(0.41)\end{array}$ & $\begin{array}{r}0.258 \\
(0.44)\end{array}$ \\
\hline Rural $^{\mathrm{a}}$ & $\begin{array}{c}0.074 \\
(0.26)\end{array}$ & $\begin{array}{c}0.140 \\
(0.35)\end{array}$ & $\begin{array}{c}0.015 \\
(0.12)\end{array}$ \\
\hline English Very Well/Well & $\begin{array}{c}0.116 \\
(0.32)\end{array}$ & $\begin{array}{c}0.116 \\
(0.32)\end{array}$ & $\begin{array}{c}0.134 \\
(0.34)\end{array}$ \\
\hline English Not Well/Not at All & $\begin{array}{c}0.006 \\
(0.08)\end{array}$ & $\begin{array}{c}0.006 \\
(0.08)\end{array}$ & $\begin{array}{r}0.007 \\
(0.09)\end{array}$ \\
\hline United Kingdom & $\begin{array}{c}0.364 \\
(0.48)\end{array}$ & $\begin{array}{c}0.415 \\
(0.49)\end{array}$ & $\begin{array}{c}0.413 \\
(0.49)\end{array}$ \\
\hline Ireland & $\begin{array}{c}0.105 \\
(0.31)\end{array}$ & $\begin{array}{c}0.106 \\
(0.31)\end{array}$ & $\begin{array}{c}0.095 \\
(0.29)\end{array}$ \\
\hline Canada & $\begin{array}{c}0.498 \\
(0.50)\end{array}$ & $\begin{array}{c}0.434 \\
(0.50)\end{array}$ & $\begin{array}{c}0.436 \\
(0.50)\end{array}$ \\
\hline Australia \& N.Z. & $\begin{array}{c}0.032 \\
(0.18)\end{array}$ & $\begin{array}{c}0.045 \\
(0.21)\end{array}$ & $\begin{array}{r}0.057 \\
(0.23)\end{array}$ \\
\hline Sample Size & 3,480 & 18,046 & 21,777 \\
\hline
\end{tabular}

${ }^{a}$ Definition of variable changes appreciably across data sets.

Sources: U.S. Censuses of Population: 1980 1\% PUMS; 1990 5\% PUMS; 2000 5\% PUMS.

Appendix Table A2

Means and Standard Deviations of Variables in Immigrant Adjustment Earnings Function, 25 to 64-Year-Old Male Immigrants from the United Kingdom, 1980, 1990 and 2000 U.S. Censuses

\begin{tabular}{lccc}
\hline Variable & 1980 & 1990 & 2000 \\
\hline Log Earnings & 9.796 & 10.377 & 10.776 \\
& $(0.93)$ & $(1.01)$ & $(1.03)$ \\
Educational Attainment & 14.485 & 14.747 & 15.181 \\
& $(3.19)$ & $2.72)$ & $(2.54)$ \\
Experience (EXP) & 23.973 & $(11.25)$ & 23.220 \\
& $(12.43)$ & 19.322 & $(10.72)$ \\
Years Since Migration (YSM) & 19.583 & $(13.35)$ & 19.549 \\
& $(12.68)$ & & $(13.81)$ \\
\hline
\end{tabular}


Appendix Table A2 Continued

Means and Standard Deviations of Variables in Immigrant Adjustment

Earnings Function, 25 to 64-Year-Old Male Immigrants from the United Kingdom, 1980, 1990 and 2000 U.S. Censuses

\begin{tabular}{lccc}
\hline Variable & 1980 & 1990 & 2000 \\
\hline Log Weeks Worked & 3.835 & 3.828 & 3.828 \\
& $(0.38)$ & $(0.39)$ & $(0.39)$ \\
Married & 0.804 & 0.714 & 0.683 \\
& $(0.40)$ & $(0.45)$ & $(0.47)$ \\
South & 0.195 & 0.248 & 0.291 \\
& $(0.40)$ & $(0.43)$ & $(0.45)$ \\
Rural $^{(a)}$ & 0.068 & 0.130 & 0.011 \\
English Very Well/Well & $(0.25)$ & $(0.34)$ & $(0.10)$ \\
& 0.047 & 0.064 & 0.088 \\
English Not Well/Not at All & $(0.21)$ & $(0.25)$ & $(0.28)$ \\
& 0.002 & 0.003 & 0.006 \\
Sample Size & $(0.05)$ & $(0.05)$ & $(0.08)$ \\
\hline
\end{tabular}

${ }^{a}$ Definition of variable changes appreciably across data sets.

Sources: 1980 Census 1\% PUMS; 1990 Census 5\% PUMS; 2000 Census 5\% PUMS.

Appendix Table A3

Means and Standard Deviations of Variables in Immigrant

Adjustment Earnings Function, 25 to 64-Year-Old Male Immigrants from Ireland, 1980, 1990 and 2000 U.S. Censuses

\begin{tabular}{lccc}
\hline Variable & 1980 & 1990 & 2000 \\
\hline Log Earnings & 9.677 & 10.278 & 10.600 \\
Educational Attainment & $(0.84)$ & $(0.88)$ & $(0.92)$ \\
& 12.568 & 13.233 & 13.899 \\
Experience (EXP) & $(3.74)$ & $(3.02)$ & $(2.71)$ \\
& 28.311 & 25.096 & 23.145 \\
Years Since Migration (YSM) & $(11.10)$ & $(12.60)$ & $(11.85)$ \\
& 23.270 & 22.029 & 18.982 \\
Log Weeks Worked & $(10.22)$ & $(14.30)$ & $(13.80)$ \\
& 3.846 & 3.816 & 3.810 \\
Married & $(0.38)$ & $(0.38)$ & $(0.43)$ \\
South & 0.809 & 0.715 & 0.621 \\
& $(0.39)$ & $(0.45)$ & $(0.49)$ \\
Rural & 0.076 & 0.113 & 0.148 \\
English Very Well/Well & $(0.27)$ & $(0.32)$ & $(0.36)$ \\
& 0.038 & 0.080 & 0.007 \\
English Not Well/Not at All & $(0.19)$ & $(0.27)$ & $(0.08)$ \\
Sample Size & 0.093 & 0.107 & 0.129 \\
\hline
\end{tabular}

${ }^{a}$ Definition of variable changes appreciably across data sets.

Sources: U.S. Censuses of Population: 1980 1\% PUMS; 1990 5\% PUMS; 2000 5\% PUMS. 


\section{Appendix Table A4}

Means and Standard Deviations of Variables in Immigrant Adjustment Earnings Function, 25 to 64-Year-Old Male Immigrants from Canada, 1980, 1990 and 2000 U.S. Censuses

\begin{tabular}{lccc}
\hline Variable & 1980 & 1990 & 2000 \\
\hline Log Earnings & 9.699 & 10.264 & 10.699 \\
Educational Attainment & $(1.01)$ & $(1.05)$ & $(1.03)$ \\
& 13.138 & 13.987 & 14.729 \\
Experience (EXP) & $(3.68)$ & $(2.99)$ & $(2.77)$ \\
& 27.172 & 22.606 & 23.334 \\
Years Since Migration (YSM) & $(13.16)$ & $(11.81)$ & $(10.88)$ \\
& 24.252 & 24.444 & 22.447 \\
Log Weeks Worked & $(12.44)$ & $(13.71)$ & $(15.64)$ \\
& 3.815 & 3.811 & 3.828 \\
Married & $(0.40)$ & $(0.40)$ & $(0.39)$ \\
& 0.821 & 0.716 & 0.685 \\
South & $(0.38)$ & $(0.45)$ & $(0.46)$ \\
& 0.152 & 0.212 & 0.254 \\
Rural & $(0.36)$ & $(0.41)$ & $(0.44)$ \\
English Very Well/Well & 0.086 & 0.169 & 0.021 \\
& $(0.28)$ & $(0.37)$ & $(0.14)$ \\
English Not Well/Not at All & 0.174 & 0.168 & 0.185 \\
Sample Size & $(0.38)$ & $(0.37)$ & $(0.39)$ \\
\hline
\end{tabular}

${ }^{a}$ Definition of variable changes appreciably across data sets.

Sources: 1980 1\% PUMS; 1990 Census 5\% PUMS; 2000 Census 5\% PUMS.

Appendix Table A5

Means and Standard Deviations of Variables in Immigrant Adjustment Earnings Function, 25 to 64-Year-Old Male Immigrants from Australia or New Zealand, 1980, 1990 and 2000 U.S. Censuses

\begin{tabular}{lccc}
\hline Variable & 1980 & 1990 & 2000 \\
\hline Log Earnings & 9.663 & 10.265 & 10.770 \\
& $(0.94)$ & $(1.29)$ & $(1.08)$ \\
Educational Attainment & 15.496 & 15.188 & 15.233 \\
& $(3.81)$ & $(3.00)$ & $(2.79)$ \\
Experience (EXP) & 16.563 & 17.950 & 20.613 \\
& $(10.73)$ & $(10.37)$ & $(10.09)$ \\
Years Since Migration (YSM) & 11.895 & 13.555 & 14.622 \\
& $(12.20)$ & $(12.05)$ & $(12.49)$ \\
Log Weeks Worked & 3.843 & 3.799 & 3.820 \\
& $(0.28)$ & $(0.45)$ & $(0.41)$ \\
Married & 0.688 & 0.637 & 0.664 \\
& $(0.47)$ & $(0.48)$ & $(0.47)$ \\
South & 0.214 & 0.211 & 0.230 \\
& $(0.41)$ & $(0.41)$ & $(0.42)$ \\
Rural $^{(\mathrm{a})}$ & 0.063 & 0.103 & 0.007 \\
& $(0.24)$ & $(0.30)$ & $(0.08)$ \\
\hline
\end{tabular}




\section{Appendix Table A5 Continued \\ Means and Standard Deviations of Variables in Immigrant \\ Adjustment Earnings Function, 25 to 64-Year-Old Male Immigrants from \\ Australia or New Zealand, 1980, 1990 and 2000 U.S. Censuses}

\begin{tabular}{lccc}
\hline Variable & 1980 & 1990 & 2000 \\
\hline English Very Well/Well & 0.080 & 0.110 & 0.090 \\
& $(0.27)$ & $(0.31)$ & $(0.29)$ \\
English Not Well/Not at All & 0.000 & 0.004 & 0.005 \\
Sample Size & $(0.00)$ & $(0.06)$ & $(0.07)$ \\
\end{tabular}

${ }^{a}$ Definition of variable changes appreciably across data sets.

Sources: U.S. Censuses of Population: 1980 1\% PUMS; 1990 5\% PUMS; 2000 5\% PUMS.

\section{REFERENCES}

Beenstock, Michael, Barry R. Chiswick, and Ari Paltiel. 2010. "Testing the Immigrant Assimilation Hypothesis with Longitudinal Data." Review of Economics of the Household, Vol. 81, pp. 7-27.

Ben-Porath, Yoram. 1967. "The Production of Human Capital and the Life Cycle of Earnings." Journal of Political Economy, Vol. 75, No. 4, Part 1, pp. 352-65.

Blau, Francine D., Lawrence M. Kahn, and Kerry L. Papps. 2011. "Gender, Source Country Characteristics and Labor Market Assimilation Among Immigrants: 1980-2000." Review of Economics and Statistics, Vol. 93, No. 1, pp. 43-58.

Borjas, George. 1995. "Assimilation and Changes in Cohort Quality Revisited: What Happened to Immigrant Earnings in the 1980s?" Journal of Labor Economics, Vol. 13, No. 2, pp. 201-45.

Card, David. 2003. "Canadian Emigration to the United States." In Charles Beach, ed., Canadian Immigration Policy for the 21st Century. Kingston, ON: John Deutsch Institute for the Study of Economic Policy.

Chiswick, Barry R. 1978. "The Effect of Americanization on the Earnings of Foreign Born Men." Journal of Political Economy, Vol. 86, No. 5, pp. 897-921.

1979. "The Economic Progress of Immigrants: Some Apparently Universal Patterns." In William Fellner, ed., Contemporary Economic Problems, pp. 357-99. Washington D.C.: American Enterprise Institute.
, and Paul W. Miller. 2008a. "Why is the Payoff to Schooling Smaller for Immigrants?” Labour Economics, Vol. 15, No. 6, pp. 1317-340. , and 2008b. "Occupational Attainment and Immigrant Economic Progress in Australia." Economic Record, Vol. 84 (September), pp. S45-S56.

Dumont, Jean-Christophe, and Georges Lemaître. 2005. "Counting Immigrants and Expatriates in OECD Countries: A New Perspective." Social, Employment and Migration Working Papers. Paris: Organisation for Economic Co-operation and Development.

Funkhouser, Edward, and Stephen J. Trejo. 1995. "The Labor Market Skills of Recent Male Immigrants: Evidence from the Current Population Survey." Industrial and Labor Relations Review, Vol. 48, No. 4, pp. 792-811.

Lindner, Deborah J. 1989. "The Determinants of Emigration and Earnings: Evidence from Canadian and U.S. Data." Diss., University of Wisconsin-Madison.

Lubotsky, Darren. 2007. "Chutes or Ladders: A Longitudinal Analysis of Immigrant Earnings." Journal of Political Economy, Vol. 115, No. 5, pp. 820-67.

McDonald, James T. and Christopher Worswick. 1998. "The Earnings of Immigrant Men in Canada: Job Tenure, Cohort, and Macroeconomic Conditions." Industrial and Labor Relations Review, Vol. 51, No. 3, pp. $465-82$.

Pedersen, Peder J., Marianne Roed, and Eskil Wadensjo. 2008. The Common Nordic Labour Market at 50. Copenhagen: Nordic Council of Ministers. 
Copyright of Industrial \& Labor Relations Review is the property of Cornell University and its content may not be copied or emailed to multiple sites or posted to a listserv without the copyright holder's express written permission. However, users may print, download, or email articles for individual use. 